\title{
Food Security and Consumption Patterns in China: The Grain Problem
}

\section{Claude Aubert}

\section{(2) OpenEdition \\ Journals}

Electronic version

URL: http://journals.openedition.org/chinaperspectives/3623

DOI: 10.4000/chinaperspectives.3623

ISSN: 1996-4617

Publisher

Centre d'étude français sur la Chine contemporaine

\section{Printed version}

Date of publication: 4 April 2008

Number of pages: 5-23

ISSN: 2070-3449

\section{Electronic reference}

Claude Aubert, «Food Security and Consumption Patterns in China: The Grain Problem », China Perspectives [Online], 2008/2 | 2008, Online since 01 April 2011, connection on 28 October 2019. URL: http://journals.openedition.org/chinaperspectives/3623; DOI : 10.4000/chinaperspectives.3623 


\title{
Food Security and
}

\section{Consumption Patterns}

\section{in China}

\author{
The Grain Problem ${ }^{(1)}$
}

Food consumption patterns remain a matter of debate in China, and different assumptions lead to very different scenarios as far as food security is concerned. In this paper we will try to clarify these patterns, mainly for grain and meat, with a view to achieving a better understanding of the significance of "food security" in China.

$\int \mathrm{t}^{\mathrm{t}}$ $\mathrm{t}$ is more than ten years now since Lester Brown launched his well known wake-up call of "Who will feed China?" (2) Apart from soybeans, the massive imports of grain ${ }^{(3)}$ Brown predicted have yet to appear (it is true that Brown's projections were made for the year 2030, so there's still time to wait for the worst); on the contrary, in the last 12 years China witnessed only three years of grain trade deficits: 1995, 1996, and 2004 (with deficits of 20, 10, and 5 million tonnes respectively), and China has actually been a net exporter since 2005. Although this situation may change, major grain exporting countries continue to await their long-anticipated grain orders from China. Where is the grain? This is a question puzzling most foreign observers of China.

Our opinion is that past projections of China's future grain needs were based on data of uneven quality from China's National Bureau of Statistics (NBSC). Food consumption patterns therefore remain a matter of debate in China, and different assumptions lead to very different scenarios as far as food security is concerned. In this paper we will try to clarify these patterns, mainly for grain and meat, in hopes of achieving a better understanding of the significance of "food security" in China.

\section{The "meat miracle"}

The term "miracle" has often been employed in describing the overall performances of the Chinese economy. ${ }^{(4)}$ But another miracle, if indeed proved, would be of great significance in assessing food consumption patterns in China. This is what we call the "meat miracle." Deng Fujiang, deputy director of the China Meat Association, stated per capita consumption of pork to be $39.6 \mathrm{~kg}$ for $2006,{ }^{(5)}$ a figure corresponding to data published by the NBSC for 2006, which show an output of 51.972 million tonnes for 1,314 million persons. ${ }^{(6)}$

In our opinion, this figure is simply false. To take one example, the pork supply per capita in Taiwan was $39.4 \mathrm{~kg}$ in 2005; can we believe it was almost exactly the same on the mainland? ${ }^{(7)}$ Even allowing for Taiwan's greater availability of poultry meat (32 kg against $12 \mathrm{~kg}$ on the mainland), it seems doubtful that China, with a rural population of 737 million (56 percent of the total population) known for its low meat consumption, could rival the advanced country of Taiwan in this respect.

Not only would the official meat output figure ( 81 million tonnes, out of which 52 million tonnes is pork) translate into an incredibly high per capita availability for China's level of economic development and urbanisation, but it would be a

1. This paper is a completely revised and updated version of one previously published in 2004 (Cf. Claude Aubert, "Consommations alimentaires: I'inconnue chinoise," in Déméter 2005, Economie et stratégies agricoles, Paris, Club Déméter, September 2004, p. 19-41).

2. Lester R Brown, Who Will Feed China? Wake-up call for a small planet, New York World Watch Institute, 1995, 163 pp.

3. In Chinese terms, "grain" (liangshi) includes cereals (with paddy in place of rice), tubers (at one fifth of their gross weight) and pulses (mainly soybean).

4. Justin Yifu Lin et al., The China Miracle, development strategy and economic reform, Hong Kong, The Chinese University Press, 1996, 330 pp.

5. China Daily, 17 September 2007.

6. NBSC, China Statistical Yearbook 2007, Beijing, China Statistics Press, 2007, pp. 105, 485.

7. Council of Agriculture, Food Supply and Utilization Yearbook, Taiwan ROC, 2005, p. 55. 
miraculous achievement based on the feed resources available in China.

Many researchers have shied away from making this calculation (meat v. feed grain) under the pretext that the great diversity in animal husbandry methods, particularly at the small farms level, subverts accurate calculation of grain/meat transformation ratios. The fact is, however, that yearly surveys have been carried out at the farm level to determine the costs and benefits of all main agricultural products. In regards to animal husbandry, detailed technical and economic data have been reported, such as the feed grain (or the fine grain, including soybean cakes and milling sub-products) used for each category of animals (pigs, poultry, etc.) and of farms (small peasant farms, middle or large sizes breeding units, etc.). These data correspond well with the average figures that we have collected in our own field surveys. Using the ratios presented in the last available survey, ${ }^{(8)}$ we can evaluate the resources required for animal products using mainly fine grain for feed (which excludes beef and mutton from the calculation, as well as grain used for aquaculture, where data is lacking). The data presented here are drawn from the relevant yearbooks for 2005 (see Table 1).

According to this calculation, about 290 million tonnes of feed grain, soybean cakes, and milling sub-products would have been needed to achieve the claimed amount of meat and animal products. The problem now is to compare this figure with the grain available for feed after deducting other uses.

Table 1. Estimates of Fine Feed Needed, based on Official Output Figures, 2005

\begin{tabular}{l|r|r|r|r|r|r}
\hline & Pork Eggs & $\begin{array}{c}\text { Poultry } \\
\text { Meat }\end{array}$ & $\begin{array}{l}\text { Cow } \\
\text { Milk }\end{array}$ & $\begin{array}{l}\text { Draught } \\
\text { Animals }\end{array}$ & Total \\
\hline Output & 50 & 29 & 12 & 28 & & \\
\hline Ratio & 3.3 & 2.4 & 2.5 & 0.55 & & \\
\hline Feed & 165 & 70 & 30 & 15 & 10 & 290 \\
\hline
\end{tabular}

Units: million tonnes, Ratio kg feed / kg output

Sources: Pork, Eggs, Cow milk = China Statistical Yearbook, 2006

Poultry meat $=$ from the 16 million tonnes of official output, 4 million tonnes have been deducted for taking into account the slaughtered hens which feed is counted with the eggs' production.

Ratio fine feed / output deduced from the Compendium of Statistics for Costs and Benefits of Agricultural Products for the Whole Country, 2006

Draught animals = on the basis of estimated numbers of oxen, horses (and mules) and donkeys used as draught animals, with respective consumption of 150,300 and $100 \mathrm{~kg}$ feed grain per head.

\section{Estimates of grain use, 2005}

Fortunately, the Grain Administration recently published balance sheets for grain usage. ${ }^{(9)}$ The presentation of the data varied somewhat in the years 2004 and 2005, but we have been able to reconstruct the distribution of each grain use, with crushed soybean counted as feed, and milling subproducts as percentages of food rice and wheat ${ }^{(10)}$ (see Table 2).

According to these official data, the available feed grain (soybean included) totalled 158 million tonnes (155 million tonnes for 2004 in the China Grain Development Report 2005), ${ }^{(I)}$ to which we add 43 million tonnes of milling subproducts. If these calculations are correct, only about 200 million tonnes of fine grain would have been available in 2005 against the total of 290 million tonnes required.

These calculations and results are not new. At a conference in London in January 1998, we made similar calculations for the year 1996, showing a gap of 45-75 million tonnes of grain. ${ }^{(12)} \mathrm{A}$ few months later, after the first results of the Agricultural Census for 1996 were published, the official figure for meat production was reduced by 22 percent to 46 million tonnes (out of which 32 million tonnes was pork). Output figures for previous years were simply dropped from the subsequent Yearbooks. The same exercise for 2001 showed a deficit of 43 million tonnes. ${ }^{(13)}$

If a third of the feed needed is lacking, does that mean the actual meat output (particularly pork) is more than 30 per-

8. Price Department, National Development and Reform Commission, Quanguo nongchan bin chengben shouyi ziliao huibian (Compendium of Materials on Costs and Benefits of Agricultural Products of the Whole Country), Beijing, China Statistics Press, 2006.

9. China Grain R \&T Center, 2006 Zhongguo liangshi fazhan baogao (China Grain Development Report 2006), Beijing, Economic Management Press, p. 106.

10. Interestingly enough, a paper by Luo Liangguo, Li Ninghui, and Yang Jiancang ("Basic judgment on grain production and consumption in China," in Nongye jingii wenti (Issues in Agricultural Economy), February 2005, pp. 49-52), referred to hereafter as "Luo 2005," presents detailed data on grain usage for the years 1999 to 2003. Total usage is compared with outputs, with separate data for rice, wheat, corn, and soybean. Then different uses (for the total amount of grain, not the separate components) are presented for the same years, differentiating seeds, losses, rural and urban food, and industria uses. The source quoted for the tables is "China's Rural Statistical Yearbook," (NBSC Zhongguo nongcun tongji nianjian, 1999-2003), but we have verified that this yearbook did not present the corresponding data. We therefore assume that the authors actually referred to unpublished data from the Grain Bureau (before they were subsequently published in the Grain Development Report).

For the year 2003, the total uses of all grains were 270 million tonnes for food, 138 million tonnes for feed, and 45 million tonnes for industrial uses. These figures are consistent with those in the Report for 2005 as deduced in Table 2.

11. Op. cit. p. 100

12. Claude Aubert, "Food Consumption and Food Production in China, statistical uncertainties, educated guesses, and reasoned optimism," in Robert Ash (ed.), China's Integration in Asia, Richmond, Curzon, 2002, pp. 99-134.

13. Claude Aubert, "Consommations alimentaires : l'inconnue chinoise," in Déméter 2005, Economie et stratégies agricoles, Paris, Club Déméter, September 2004, pp. 19-41. 
Table 2 . Estimates of Grain Uses, Grain Development Report, 2005

\begin{tabular}{|c|c|c|c|c|c|c|}
\hline & Total & Paddy & Wheat & Maize & Other Gr. & Soybean \\
\hline Output & 484 & 181 & 97 & 139 & 51 & 16 \\
\hline Importations & 33 & 1 & 3 & 0 & 2 & 27 \\
\hline Exports & 10 & 1 & 0 & 9 & 0 & 0 \\
\hline Total Available & 507 & 181 & 100 & 130 & 53 & 43 \\
\hline Food & 261 & 150 & 88 & 10 & 10 & 3 \\
\hline Feed & 158 & 14 & 4 & 89 & 25 & 26 \\
\hline Industry & 48 & 10 & 2 & 20 & 10 & 6 \\
\hline Other & 40 & 7 & 6 & 11 & 8 & 8 \\
\hline Milling Sub-Products & 43 & 30 & 13 & & & \\
\hline Fine Feed & 201 & 44 & 17 & 89 & 25 & 26 \\
\hline
\end{tabular}

Table 3. Estimates of Food Grain Consumption, 2005

\begin{tabular}{|c|c|c|c|c|c|c|c|c|}
\hline & \multicolumn{4}{|c|}{ Ration per capita } & \multicolumn{3}{|c|}{$\begin{array}{l}\text { Total Consumption } \\
\text { Personal Estimates }\end{array}$} & \multirow{2}{*}{$\begin{array}{c}\text { Total } \\
\text { Consumption } \\
\text { Estimates } \\
\text { Grain Bureau } \\
\text { Report }\end{array}$} \\
\hline & $\begin{array}{l}\text { Urban } \\
\text { Net }\end{array}$ & $\begin{array}{l}\text { Urban Net } \\
\text { Rectified }\end{array}$ & $\begin{array}{l}\text { Urban Gross } \\
\text { Rectified }\end{array}$ & $\begin{array}{l}\text { Rural } \\
\text { Gross }\end{array}$ & Urban & Rural & Total & \\
\hline paddy & 41.81 & 52.26 & 80.40 & 113.36 & 45.20 & 84.50 & 129.70 & 150 \\
\hline wheat & 32.08 & 40.10 & 50.13 & 68.44 & 28.18 & 51.02 & 79.20 & 88 \\
\hline maize & 3.08 & 3.85 & 3.85 & 14.20 & 2.16 & 10.59 & 12.75 & 10 \\
\hline $\begin{array}{l}\text { other } \\
\text { grain }\end{array}$ & 12.37 & 15.46 & 15.46 & 10.90 & 8.69 & 8.13 & 16.82 & 10 \\
\hline pulses & 6.50 & 8.13 & 8.13 & 3.30 & 4.57 & 2.46 & 7.03 & (soybean) 3 \\
\hline total & 95.84 & 119.80 & 157.97 & 210.20 & 88.80 & 156.70 & 245.50 & 261 \\
\hline
\end{tabular}

cent lower than the official figure? For pork alone, the resulting supply figure of $28 \mathrm{~kg}$ per capita would be more in line with the structure of population and present state of development of the economy.
As feed grain is usually calculated as the remainder of grain available after deducting all other uses, it would be interesting to verify the plausibility of the figure of 155-157 million tonnes given in the Grain Bureau Report. For this purpose, 
Table 4. Grain Uses, Personal Estimates, 2005

\begin{tabular}{|c|c|c|c|c|c|c|}
\hline & Total & Paddy & Wheat & Maize & Other Gr. & Pulses \\
\hline Output & 484 & 181 & 97 & 139 & 45 & 22 \\
\hline Seeds & 11 & 1 & 5 & 1 & 3 & 1 \\
\hline Losses & 30 & 10 & 5 & 11 & 3 & 1 \\
\hline Net Output & 443 & 170 & 87 & 127 & 39 & 20 \\
\hline Imports & 33 & 1 & 3 & 0 & 2 & 27 \\
\hline Exports & 10 & 1 & 0 & 9 & 0 & 0 \\
\hline Grain Available & 466 & 170 & 90 & 118 & 41 & 47 \\
\hline Food & 246 & 130 & 79 & 13 & 17 & 7 \\
\hline Feed & 160 & 14 & 2 & 95 & 18 & 31 \\
\hline Industry & 46 & 10 & 2 & 20 & 6 & 8 \\
\hline Stocks & 14 & 16 & 7 & -10 & 0 & 1 \\
\hline Milling Sub-Products & 36 & 25 & 11 & & & \\
\hline Fine Feed & 196 & 39 & 13 & 95 & 18 & 31 \\
\hline \multicolumn{6}{|c|}{$\begin{array}{l}\text { Source: Output, Imports and Exports = China Statistical Yearbook } 2006 \\
\text { Pulses include soybean } \\
\text { Food, Feed and Industry = estimates } \\
\text { Milling sub-products = estimates } \\
\text { Fine feed = feed grain, milling sub products and soybean cakes }\end{array}$} & Unit: million tonne \\
\hline
\end{tabular}

we propose to begin by calculating grain food consumption for the year 2005 (see Table 3). The details of the food ration for the rural population are available in the China Yearbook of Rural Household Survey, ${ }^{(14)}$ with figures for cereals expressed in un-milled terms (paddy, wheat). Those of the urban population are to be found in the China Urban Life and Price Yearbook ${ }^{(5)}$ and are expressed in terms of amounts milled for cereals (rice, flour), and more generally concern only the quantities purchased. In order to take out-of-door consumption into account, the reported rations have been multiplied by a coefficient of 1.25 (urban net rectified figure). The ratio of milled rice to paddy is estimated at 0.65 , and that for flour/wheat at 0.8 in order to convert the net (milled) figures of the urban rations to their gross equivalents.

Our total food grain estimate, 246 million tonnes, is lower than that of the Grain Bureau Report (261 million tonnes). The difference probably stems from the Bureau calculation using the "countryside population" reported in the "Agriculture" Chapter of the China Statistical Yearbook (949 million persons) ${ }^{(16)}$ instead of the rural population as defined in the "Population Chapter" (745 million persons). ${ }^{(17)}$ If the calculations in Table 3 are based on gross food grain rations distributed on the basis of 949 million "rural" inhabitants and 359 "urban" inhabitants, the result is total food consumption of 256 million tonnes, a figure close to the bureau's 263 million tonnes. ${ }^{(18)}$

14. National Bureau of Statistics of China, Zhongguo nongcun zhuhu diaocha nianjian 2006 (China Yearbook of Rural Household Survey 2006), Beijing, China Statistics Press, 2006.

15. National Bureau of Statistics of China, 2006 Zhongguo chengshi (zhen) shenghuo yu jiage nianjian (China Urban Life and Price Yearbook 2006), Beijing, China Statistics Press. For the previous years the survey was published under the name of Zhongguo jiage ji chengzhen jumin jiating shouzhi diaocha tongji nianjian (China Statistical Yearbook of Prices and Survey of Incomes and Expenses of Urban Households).

16. China Statistical Yearbook 2006, p. 463.

17. Ibid. p. 99 
If feed and industrial uses of grain from the Grain Bureau Report seem reliable enough, the residual "other" category deduced from this report is too vague to be accurately interpreted. We have therefore drawn our own balance sheet of grain uses for the year 2005 , to be compared with that presented in Table 2 (see Table 4).

In this table, seeds usage has been deduced from the yearly report of Agricultural Costs and Benefits, and losses calculated at an average of 6 percent of total output. The food uses are those estimated in Table 3, and most of the figures for feed and industrial uses are derived from the Grain Bureau Report. The total feed has been adjusted to correspond to the needs that we will present later in this paper, following new estimates of meat outputs. This allowed us to calculate the changes in stock for feed from the residual figures produced after deducting food and industrial uses.

These changes in the stock seem to confirm the plausibility of our usage figures. In particular, wheat supply was already in surplus in 2005, and market prices began to drop at the end of the year. The trend was reversed in 2006 through massive procurements by the State at floor-level prices, which resulted in an artificial scarcity at the end of 2006 and inflation of flour prices. Since then, the harvest continued to increase in 2006 (104 million tonnes) but the prices have still been pushed up by international wheat deficits. As for corn, a deficit seems to have already appeared in 2005, fuelled by increased use in the production of bio-ethanol. Since then, prices have shot up in China as well as in the rest of the world, despite a record harvest of 145 million tonnes.

Comparing the two sets of estimates (Tables 2 and 4), it is interesting to note that the decrease in the food use figure in our estimate is offset by adding the changes of stocks, so that the availability for feed and industrial usage are equivalent. More to the point, in the two balance sheets for grain usage, the feed available for animal husbandry is about the same, in round figures 160 million tonnes of feed grain (including soybean cakes), plus 40 million tonnes of milling sub-products. The total fine feed availability, 200 million tonnes, is still 100 million short of the 300 million tonnes implicitly required by the official data for meat (and other animal products). ${ }^{(19)}$

Needless to say, our reasoning assumes that official grain output data are accurate. ${ }^{(20)}$ This assumption could be questioned in view of the huge uncertainties concerning cultivated land, and we have already analysed this issue in another paper. ${ }^{(21)}$ We compared the provincial data of land surveys from the 1980s (published in Chinese in 1992) and of
Table 5. Estimates of Rural Grain Rations, $1985-2005$

\begin{tabular}{l|r|r|r|r|r}
\hline & 1985 & 1990 & 1995 & 2000 & 2005 \\
\hline paddy & 136 & 135 & 129 & 127 & 113 \\
wheat & 73 & 80 & 81 & 80 & 69 \\
maize & 20 & 20 & 20 & 20 & 14 \\
tubers & 12 & 12 & 10 & 9 & 3 \\
other cereals & 15 & 15 & 12 & 11 & 8 \\
pulses & 2 & 3 & 4 & 5 & 3 \\
total & 258 & 265 & 256 & 252 & 210 \\
\hline
\end{tabular}

Unit: $\mathrm{kg} / \mathrm{capita} / \mathrm{year}$

Source: NBSC rural surveys and estimates.

$N B$ : The rations are expressed in un-milled terms

the Census of 1997. Taking into account the inclusion of non-agricultural lands (canals, dirt roads) and the fact that, out of 127 million hectares cultivated in 2001, 21 million corresponded to temporarily cultivated land, ${ }^{(22)}$ we concluded that this issue did not significantly change crop outputs. With respect to grain, it seems that if the sown surfaces are indeed underestimated, observed yields are voluntarily increased by the teams of the Statistical Bureau in order to take measured underestimates into account and produce reliable output figures.

In short, there is no "meat miracle" in China, but an overestimation in which actual output could be as low as 70 per-

18. This is confirmed by the "Luo 2005" paper, which counts the "rural" population as that presented in the "Agriculture" Chapter of the China Statistical Yearbook (935.5 million rural inhabitants in 2003, etc.).

19. Long ago, J.R. Simpson (J.R. Simpson, Xu Cheng, and Akira Miyazaki, China's Livestock and Related Agriculture, Projections to 2025, Wallingford, CAB International, 1994, p. 474) demonstrated that the "final result of demand and supply side projections of animal feedstuffs shows that 36 percent of the metabolisable energy requirements in 1989-91 [...] cannot be accounted for by using published statistics or derived through calculations" (Ibid. p. 370). In their less technical, more economics-oriented study, Garnaut and Ma also noticed differences between fine feed consumption figures depending on whether estimates were derived through the demand or supply approach (Ross Garnaut and Guonan Ma, Grain in China, Canberra, Australian Government Publishing Service, 1992, p. 151). The authors did not elaborate beyond arguing that food and feed grain uses cannot be easily distinguished in the small-scale framework of peasant farms. In 1997, Zhong Funing already stressed the over-reporting of meat output statistics ("Exaggeration and Causes of Meat Production Statistics Over-reporting in China," in Zhongguo nongcun jingji (Chinese Rural Economy), October 1997, pp. 63-66)

20. Detailed output data for each grain are available in "China's Agriculture Yearbook" (Ministry of Agriculture, Zhongguo nongye nianjian, Beijing, China Agriculture Press).

21. Claude Aubert, "Of men, grain and pigs, puzzling out the statistical mysteries of China," Unpublished paper for the Inaugural Symposium of the White Rose East Asia Centre, Sheffield, May 2007

22. China Statistical Yearbook, 2006, p. 465 
Table 6. Estimates of Urban Grain Rations, $1985-2005$

\begin{tabular}{l|r|r|r|r|r|r}
\hline & 1985 & 1990 & 1995 & 2000 & 2005 \\
\hline paddy & 115 & 102 & 110 & 87 & 80 \\
wheat & 65 & 70 & 53 & 50 & 50 \\
maize and & 6 & 5 & 3 & 4 & 4 \\
other cereals & 15 & 15 & 16 & 16 & 16 \\
tubers & 15 & 8 & 8 & 8 & 8 \\
pulses & 8 & 200 & 190 & 165 & 158 \\
total & 209 & & & & \\
\hline
\end{tabular}

Unit: $\mathrm{kg} / \mathrm{capita} / \mathrm{year}$

Source: NBSC urban surveys and estimates.

$N B$ : The rations are expressed in un-milled terms

cent of the claimed figure. We will return to this issue in a later section of this paper.

\section{Trends in food grain uses}

Before tackling the vexing issue of meat output estimates, the preceding calculation has shown that it was possible to assess food grain consumption for the year 2005. As the data we used for that purpose are (for the most part) available in the rural and urban surveys carried out by the Statistical Bureau for more than 20 years (the results for 2005 being published in the respective 2006 yearbooks already quoted), it should be possible to trace back past trends in food grain consumption. That's exactly what we have done, distinguishing between rural and urban consumption for the main grains (paddy, wheat, corn, tubers, other cereals, and pulses) in the years 1985 to 2005.

In the rural surveys, food grain consumption is expressed in gross (un-milled) terms, and "grain" includes tubers, but not pulses, which are counted separately. In the urban surveys (at least for the most recent years), grain includes only cereals, with both tubers and pulses counted separately (data for pulses are lacking since 2002). In these urban surveys, cereals are expressed in milled terms (rice instead of paddy, flour and flour products instead of wheat). The rations presented in Tables 5 and 6 are all expressed in un-milled terms (the usual transformation ratios have been applied to paddy and wheat), and include tubers and pulses. In years where data are lacking (mainly for corn, other cereals, tubers, and pulses), estimates have been made by extrapolation from other years. The resulting total rations are consistent with the official totals (the urban figures being multiplied by a factor of 1.15 to 1.25 in order to take out-of-doors consumption into account). ${ }^{(23)}$

For convenience, in the above tables we have only presented the figures for 1985, 1990, 1995, 2000 and 2005. Both rural and urban rations decreased during this 20-year period, but the urban ration decreased more rapidly than the rural ration, by 25 percent as against 20 percent. ${ }^{(24)}$

In fact, the rural ration began its significant decrease only in the last five years. During the first 15 years, while paddy rations declined from $136 \mathrm{~kg}$ to $127 \mathrm{~kg}$ (113 kg in 2005), wheat rations increased from 73 to $80 \mathrm{~kg}$ (but dropped to $69 \mathrm{~kg}$ in 2005). Throughout this time, secondary grain was replaced by the more refined wheat in Northern areas. In 1985, secondary cereals and tubers totalled 18 percent of the whole ration, but made up only 12 percent by 2005 .

The decrease in the urban ration has been constant over time, in line with grain consumption being replaced by meat and animal products. While paddy consumption decreased steadily and precipitously ( $115 \mathrm{~kg}$ in 1985 to $80 \mathrm{~kg}$ in 2005), the wheat ration has been stable in recent years (at $50 \mathrm{~kg}$, against $65 \mathrm{~kg}$ in 1985). In the case of wheat, direct consumption of flour for noodles or steamed bread has been partly replaced by processed products (biscuits, etc.). As for secondary cereals and tubers (Irish potatoes), contrary to the situation in the countryside, urban consumption has maintained a low but steady level of about $20 \mathrm{~kg}$, with ration share increasing from 10 percent in 1985 to 17 percent in 2005. Also of interest is the consistently high urban consumption of pulses (mainly in the form of "tofu") at $8 \mathrm{~kg}$ as against only $3 \mathrm{~kg}$ in the countryside.

Applying the calculated rations to the rural and urban populations, it is now possible to reconstitute the grain consumption trends of the last 20 years. We have retained for this calculation the "rural" and "urban" population figures presented in the "Population" chapter of the Statistical Yearbooks,

23. The rations as calculated in the Tables 5 and 6 do not correspond with the totals quoted in "Luo 2005." According to that paper, the rural ration decreased from $237 \mathrm{~kg}$ in 1999 to 214 in 2003, and the urban ration remained basically unchanged at about $200 \mathrm{~kg}$. As the details of calculation are not explained, it is difficult to assess the reliability of these data.

24. The rations quoted for the years 1985, 1990, 1995, and 2001 to 2003, by Tian Weiming and Zhou Zhangyue (Chapter 5, p. 81 sq., in Zhang-Yue Zhou and Wei-Ming Tian, Grains in China, foodgrain, feedgrain and world trade, Aldershot, Ashgate, 2005, 255 pp., hereafter "Zhou and Tian 2005") correspond exactly with our estimates for the rural ration, decreasing from $258 \mathrm{~kg}$ in 1985 to $224 \mathrm{~kg}$ in 2003. However, the figures for urban rations, expressed in milled terms, show a greater decline, from $135 \mathrm{~kg}$ to $80 \mathrm{~kg}$, a decrease of 40 percent against our estimated 25 percent. This difference is due to Tian and Zhou not taking out-of-door consumption into account ( $80 \mathrm{~kg}$ is indeed the official figure for purchases of grain by urban households), as a result of which their rural and urban data are not comparable. 
Graph 1. Rural Grain Food Consumption, 1985 - 2005 (million tonnes)

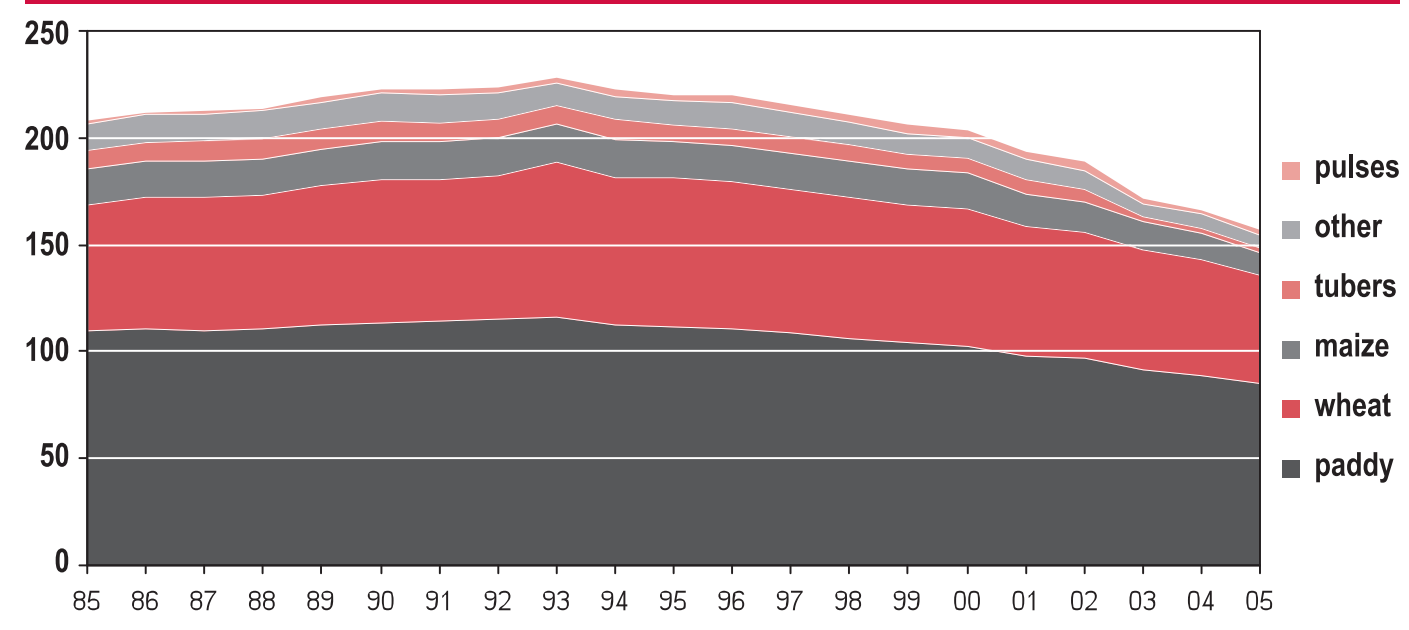

Graph 2. Urban Grain Food Consumption, 1985 - 2005 (million tonnes)

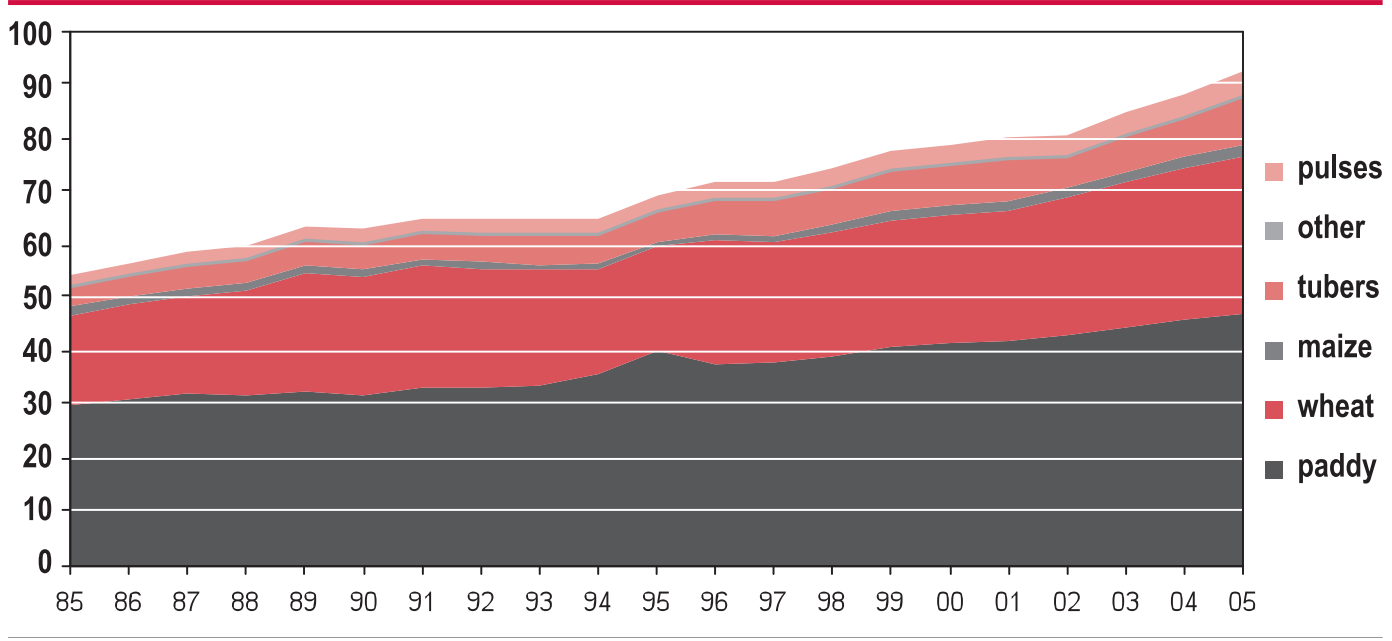

Graph 3. Total Grain Food Consumption, 1985 - 2005 (million tonnes)

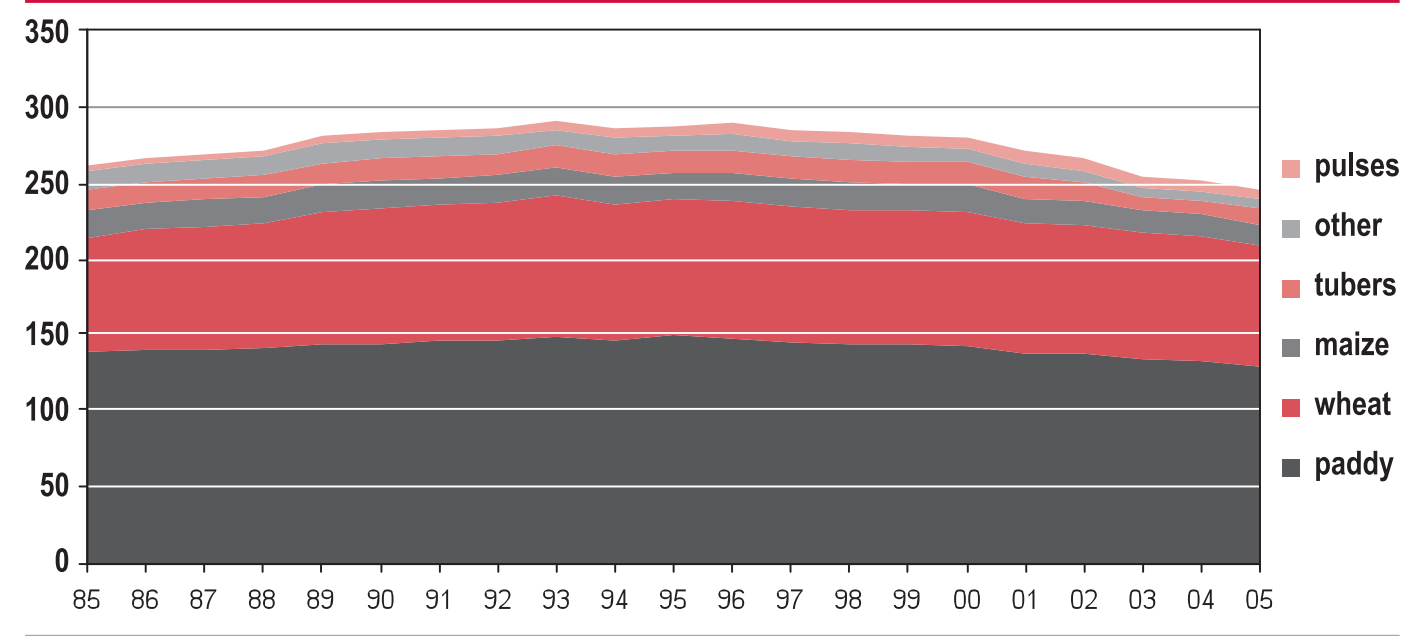


Table 7. Official Meat Rations and Resulting Consumptions

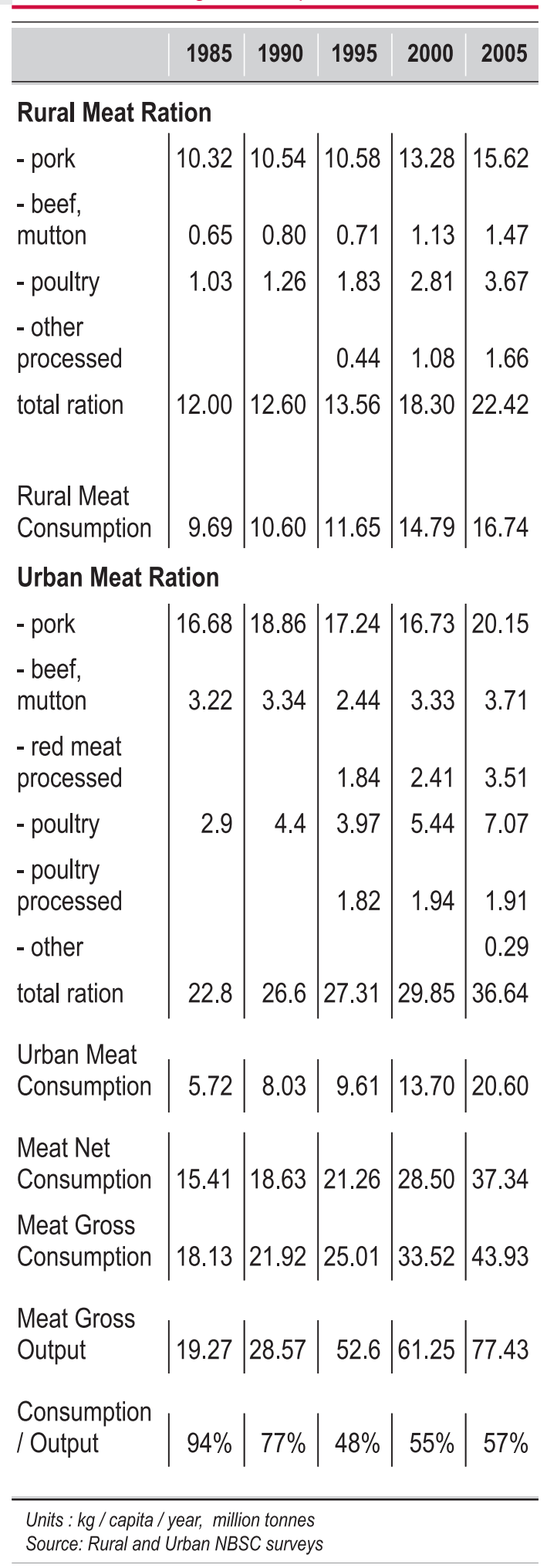

Table 8. Estimates of Fine Feed Needed, based on Estimated Output Figures, 2005

\begin{tabular}{|c|c|c|c|c|c|c|}
\hline & 뜽 & $\begin{array}{l}\text { 용 } \\
\text { 묘 }\end{array}$ & 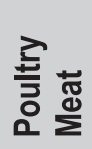 & $\begin{array}{l}\text { 恶 } \\
\text { 方 } \\
\text { ن }\end{array}$ & 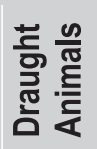 & $\begin{array}{l}\bar{J} \\
\text { 으 }\end{array}$ \\
\hline Output & 35 & 14 & 9 & 28 & & \\
\hline Ratio & 3.3 & 2.4 & 2.5 & 0.55 & & \\
\hline Feed & 115 & 34 & 22 & 15 & 10 & 196 \\
\hline
\end{tabular}

Units : million tonnes, Ratio $\mathrm{kg}$ feed / $\mathrm{kg}$ output

Source: Pork, Eggs, Poultry meat = estimates; Cow milk = China Statistical Yearbook, 2006; Poultry meat = from our estimates of 11 million tonnes output, 2 million tonnes have been deducted for taking into account the slaughtered hens which feed is counted with the eggs' production.

as these employ the demographical definitions of the Census (the "rural" population given in the "Agriculture" chapter corresponds with that included in the geographical limits of the past People's Communes, and includes urban dwellers of townships and small towns (zhen)).

The choice of these figures is all the more important given that urban rations are much lower than rural rations, with the differential increasing over time (urban rations were 19 percent lower than rural rations in 1985, and 25 percent lower in 2005). The urbanisation process is, therefore, the main factor modelling the trends in food grain consumption. ${ }^{(25)}$ The urbanisation rate was 24 percent in 1985 (251 million urban against 808 million rural people), 26 percent in 1990 (302 million against 841 million), 29 percent in 1995 (352 million against 859 million), 36 percent in 2000 (459 million against 808 million), and 43 percent in 2005 (562 million against 745 million). This increase in urban residents, particularly rapid in the last five years, coupled with the drop in rural and urban rations, explains the trends in food grain consumption shown in the following graphs.

The drop is particularly spectacular for total rural food grain consumption (see Graph 1). After a peak of 228 million tonnes in 1993, the total was only 157 million in 2005. Paddy and wheat consumption shows a similar pattern: 116 million tonnes of paddy in 1993, and 85 million

25. Fred Gale estimates that migrants, the main driving factor in the urbanisation process, have contributed to the decrease in food grain consumption by adjusting their grain consumption to that of low-income urban dwellers. Fred Gale et al., "Analysis on the commercialisation of rural residents' food consumption in China," in Zhongguo nongcun jingji (Chinese Rural Economy), April 2006, p. 10. 
Graph 4. Meat Output Estimates, 1985 - 2005 (Unit: million tonnes)

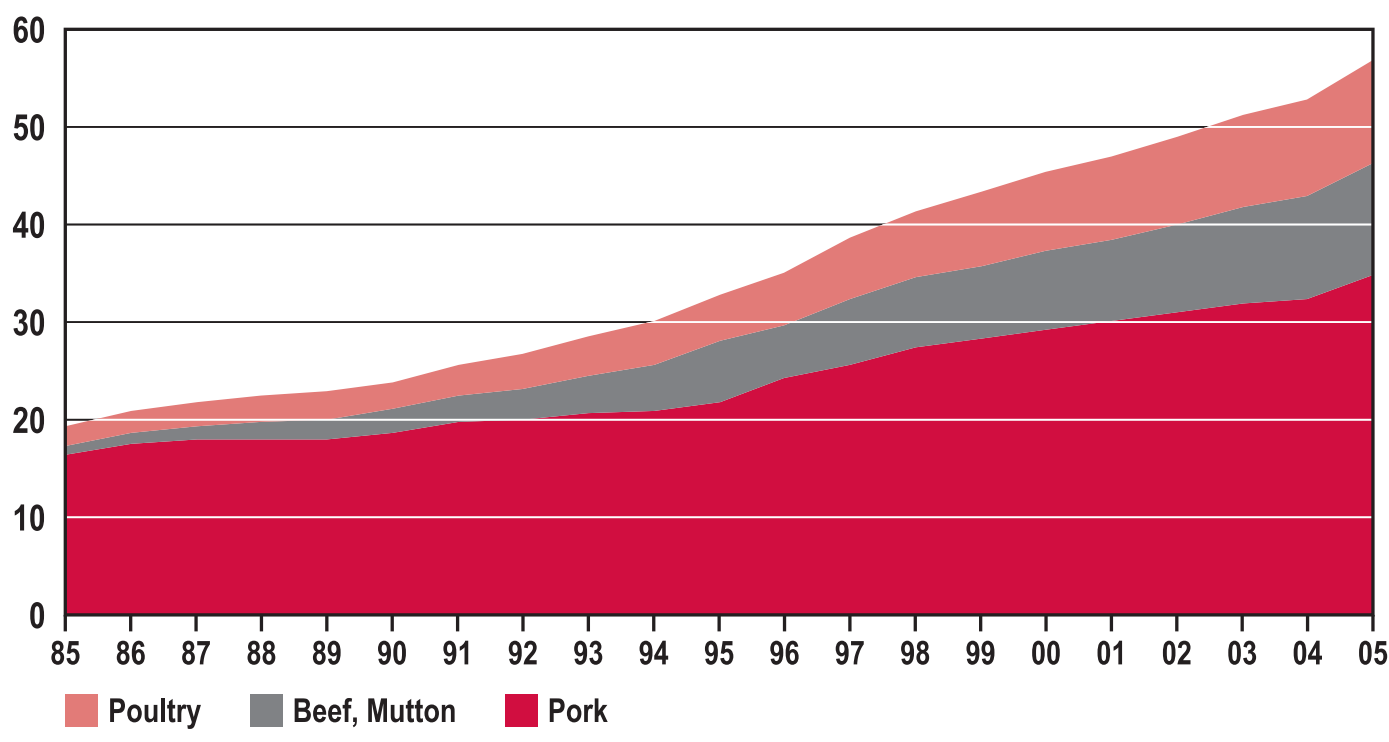

in 2005; 72 million tonnes of wheat in 1993, and 51 million in 2005. Whereas total consumption exceeded 200 million tonnes during the first 15 years, it dropped by more than 40 million tonnes in the last five years. This corresponds closely with the recent decrease in rural rations already noted, as well as with the rising wave of migrant workers (nongmingong) leaving the countryside in recent years.

Conversely, the urban total food grain consumption has continued to increase in spite of the drop in rations (see Craph 2). It grew from 52 million tonnes in 1985 to 89 million tonnes in 2005. Paddy increased from 29 to 45 million tonnes, and wheat from 16 million tonnes to 28 million.

The resulting trends in total food grain consumption are therefore of primary interest in assessing the future (see Graph 3). Beginning at 262 million tonnes in 1985, the total reached its maximum level of 291 million tonnes in 1993, then dropped to 246 million tonnes in 2005. Paddy consumption, after a slow increase from 138 million tonnes in 1985 to 149 million tonnes in 1993, decreased to 130 million tonnes in 2005. The initial increase in wheat consumption was more marked than that of paddy, from 75 million tonnes in 1985 to 93 million in 1993, before it decreased to 79 million tonnes in 2005. Whereas paddy consumption was lower at the end of the period compared with the beginning, wheat consumption remains slightly higher, but the trend is clearly on the decrease, with consumption at 88 million tonnes in 2000, compared with 79 million in 2005. ${ }^{(26)}$

\section{Estimates for meat and other animal products}

Given that the official figures on total meat output are probably wrong, one needs to turn to estimates in order to reconstitute past trends in meat output and corresponding feed grain uses.

The official meat rations reported in the surveys of the NBSC, multiplied by the corresponding numbers of rural and urban residents, result in a total consumption much lower than the officially stated outputs (see Table 7).

After converting the net meat total consumption derived from the rations to gross consumption (carcass losses estimated at 15 percent of the gross weight), consumption appears to be only 55 percent of the official total meat output (in carcass terms). More interestingly, consumption corresponded roughly to output in 1985, but the ratio declined to 48 percent in 1995, before the rectification of meat outputs in 1996. Since then, consumption seems to have remained at 55 percent of official output. If official rations were to be believed, the overestimation of meat output

26. In "Luo 2005," the unexplained data for urban and rural rations, plus the use of the inflated "countryside" rural population figures, results in questionable total food grain consumption figures. Although it decreases from 283 million tonnes in 1999 to 270 million tonnes in 2003, this drop in consumption is less marked than in our estimates. Moreover, no desegregated figures are available for paddy, wheat, corn, etc. As for Zhou and Tian (2005), they do not calculate the resulting totals of food grain consumed by rural and urban people. 
Graph 5. Meat Output, Estimates and Official, 1985 - 2005 (Unit: million tonnes)

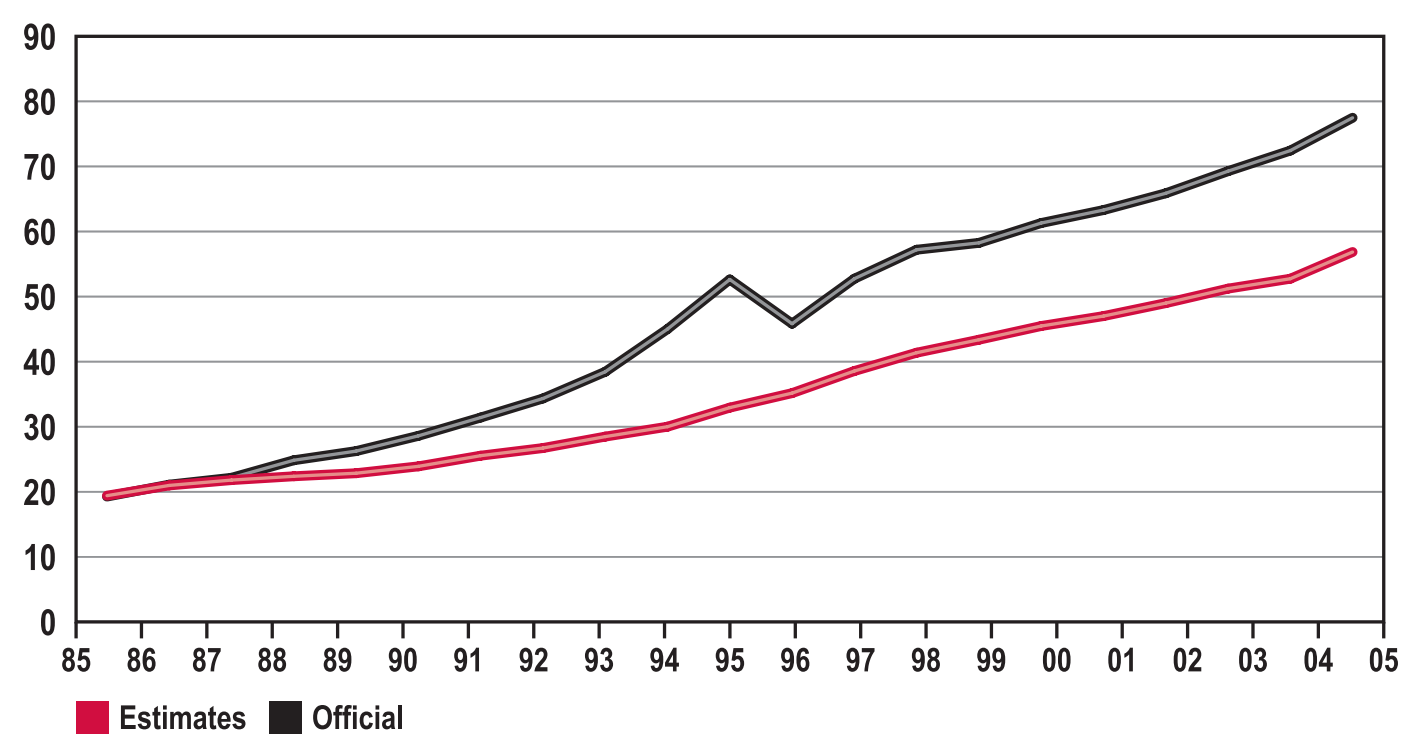

should be much higher than that previously derived from feed resource estimates (in which meat and other animal products were considered only one third lower than official figures).

The problem is again that of out-of-doors meat consumption by urban dwellers. This problem is further complicated as processed meat (mainly pork) appears only after 1990, rendering the whole ration series inconsistent. Estimates of outof-doors meat consumption is a matter of guess, so other ways must be found to assess meat output and its past trends. ${ }^{(27)}$ For that purpose some arbitrary estimates will have to be made, and the calculations we present below are open to debate.

First, we have tried to define production levels for animal products relying on feed grain, consistent with the overall figure for availability of feed resources in 2005 (160 million tonnes of feed grain, or 200 million tonnes of fine feed). Using the same grain/meat ratios as in the Table 1, we get total needs of about 195 million tonnes of fine feed with estimated outputs of 35 million tonnes of pork (against the official figure of 50 million), 14 million tonnes of eggs (against 29 million), 11 million tonnes of poultry meat (against 16 million), and the same figure as the official one for cow milk (and estimates for draught animals). Our estimates are therefore 30 percent less than the official figures for pork and poultry meat, and our egg estimate is only 50 percent of the official figure (see Table 8).

Reconstructing the past evolution of meat (and other related animal husbandry products) is even more risky. We made calculations for pork, poultry meat, and eggs (cow milk being unchanged), but for the sake of convenience only the case of pork will be detailed here. To make things simple, we have retained the official rural pork rations on the assumption that they are reliable. Urban ration estimates ranged from $22 \mathrm{~kg}$ (17 kg official) in 1985 to $32 \mathrm{~kg}(20 \mathrm{~kg}$ official) in 2005. ${ }^{(28)}$ The net meat output was estimated at 85 percent of total gross output (carcass weight). In 1985, the resulting total estimated output (carcass weight) was 16.30 million tonnes, similar to the official figure of 16.55 million tonnes. In 2005, the estimated output was 34.86 mil-

27. In "Zhou and Tian 2005," Wang Jimin and Zhou Zhangyue (Chapter 6, pp. 87-107, hereafter "Wang and Zhou 2005") present very original and interesting estimates of meat consumption. After making the same observation that we did regarding official consumption being much lower than output, they try to reconcile the official meat output with real data for consumption. To that end they use a sample survey of their own made in 1998, in which they observed rural and urban consumption, including processed meat and out-of-door consumption. On this basis, taking pork as an example, they arrive at a ration of $24 \mathrm{~kg}$ per capita in 2000, against the official gross availability figure of $32 \mathrm{~kg}$. The difference is attributed to a high carcass loss rate of 24 percent.

28. For 2005, if we suppose that the processed red meat presented in the official urban meat ration is mainly pork, then the total pork (and pork products) bought would be $24 \mathrm{~kg}$. Our estimated total urban ration of $32 \mathrm{~kg}$ would put out-of-door consumption at $8 \mathrm{~kg}$, or 25 percent of the total ration (for 1998, the percentage of away-from-home urban consumption of pork was estimated at 27 percent by Wang and Zhou; Cf. "Wang and Zhou 2005"). The multiplying ratio required to take account of this out-of-door consumption would be 1.33 , compared with the ratio of 1.25 used for the food grain urban ration.

On. the other hand, Wang and Zhou's observations for the pork rural ration in 1998 are probably too high due to higher-than-average incomes, with $19 \mathrm{~kg}$ against the official $13 \mathrm{~kg}$ (retained in our calculations). This results in a total net consumption of pork of 31 million tonnes for the year 2000, against our estimated 25 million tonnes (or 29 million tonnes carcass weight, with a carcass weight loss rate of 15 percent). The official figure for that year was 40 million tonnes. 
Table 9. Feed Grain Uses, Estimates, $1985-2005$

\begin{tabular}{|c|c|c|c|c|c|}
\hline & 1985 & 1990 & 1995 & 2000 & 2005 \\
\hline Pork Output & 16.30 & 18.69 & 21.87 & 29.24 & 34.86 \\
\hline Grain/Pork Ratio & 4.50 & 4.05 & 3.80 & 3.55 & 3.30 \\
\hline Fine Feed Needed & 73.35 & 75.70 & 83.11 & 103.79 & 115.04 \\
\hline Eggs Output & 4.07 & 5.27 & 7.76 & 11.94 & 13.89 \\
\hline Grain/Eggs Ratio & 4.10 & 3.60 & 3.00 & 2.55 & 2.40 \\
\hline Fine Feed Needed & 16.69 & 18.98 & 23.29 & 30.44 & 33.35 \\
\hline Poultry Meat & 2.04 & 2.86 & 4.87 & 8.13 & 10.53 \\
\hline Poultry Meat Rectif. & 1.50 & 2.15 & 3.84 & 6.54 & 8.68 \\
\hline Grain/Poultry Ratio & 4.00 & 3.15 & 2.60 & 2.50 & 2.50 \\
\hline Fine Feed Needed & 5.99 & 6.78 & 9.98 & 16.36 & 21.71 \\
\hline Cow Milk Output & 2.50 & 4.16 & 5.76 & 8.27 & 27.53 \\
\hline Grain/Milk Ratio & 0.55 & 0.55 & 0.55 & 0.55 & 0.55 \\
\hline Fine Feed Needed & 1.37 & 2.29 & 3.17 & 4.55 & 15.14 \\
\hline Draught Animal Feed & 9.14 & 10.28 & 11.45 & 9.54 & 10 \\
\hline Total Fine Feed & 106.53 & 114.03 & 131.01 & 164.67 & 195.24 \\
\hline - feed grain & 69.69 & 74.21 & 90.13 & 125.26 & 159.51 \\
\hline - milling sub-products & 36.84 & 39.82 & 40.88 & 39.41 & 35.73 \\
\hline
\end{tabular}

lion tonnes against the official figure of 50.11 million tonnes. Ration estimates for the intermediate years have been somewhat arbitrary, following an $\mathrm{S}$ curve, with an increased rate of growth for the years 1990-2000.

A similar calculation was made for poultry meat, and official figures were retained for beef and mutton productions (as these products were not assumed to be mainly fed on grain). The resulting meat output trends are presented in Graph 4.

If our assumptions are correct, pork would have increased by 3.9 percent yearly from 1985 to 2005 (with a doubling of output, 16 to 35 million tonnes) instead of the 5.7 percent ( 17 to 50 million) recorded in official data. For the last five years, both rates of growth were comparable, around 4 percent (3.6 percent for our estimates, 4.4 percent for the official data). The yearly rates of growth for poultry meat were more than the double those for pork, at an estimated 8.6 percent (resulting in a quintupling of the output, from 2 million tonnes in 1985 to 11 million in 2005). The growth in output of beef and mutton was the fastest, at 12.6 percent annually (from 1 million to 11 million tonnes).

The total estimated output of meat, 57 million tonnes (or 44 $\mathrm{kg}$ per capita), would be about 25 percent lower than the official 77 million tonnes (see Graph 5). For the year 2005, pork would represent only 61 percent of the total output (down from 84 percent in 1985), and the per capita gross availability would be $27 \mathrm{~kg}$ (compared with the official $38 \mathrm{~kg}$ ).

Although lower than the official data for pork and poultry, our estimated figures still indicate impressive performance in meat production over the last 20 years. 
Graph 6. Feed Grain Uses, Estimates, 1985 - 2005 (Unit: million tons)

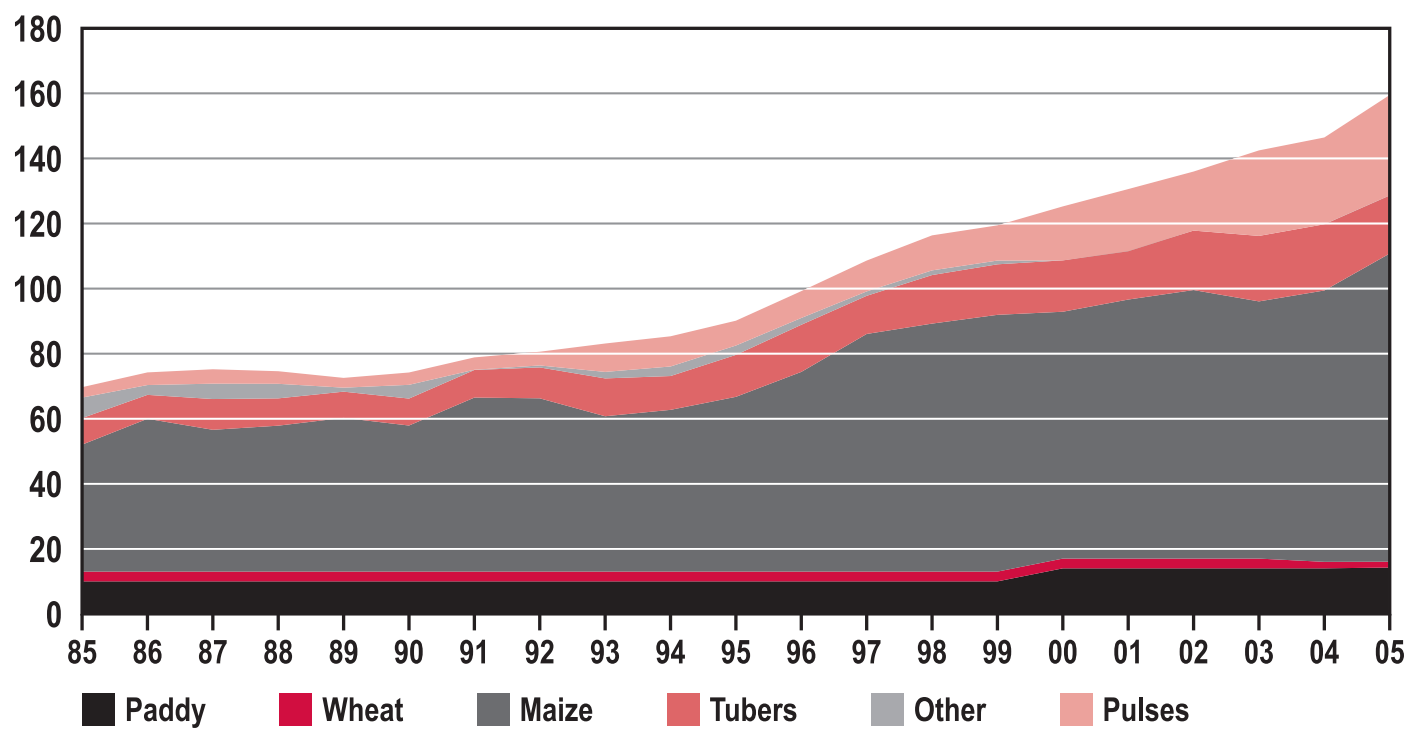

Graph 7. Estimates of Feed Grain Distribution, 1985, 2005

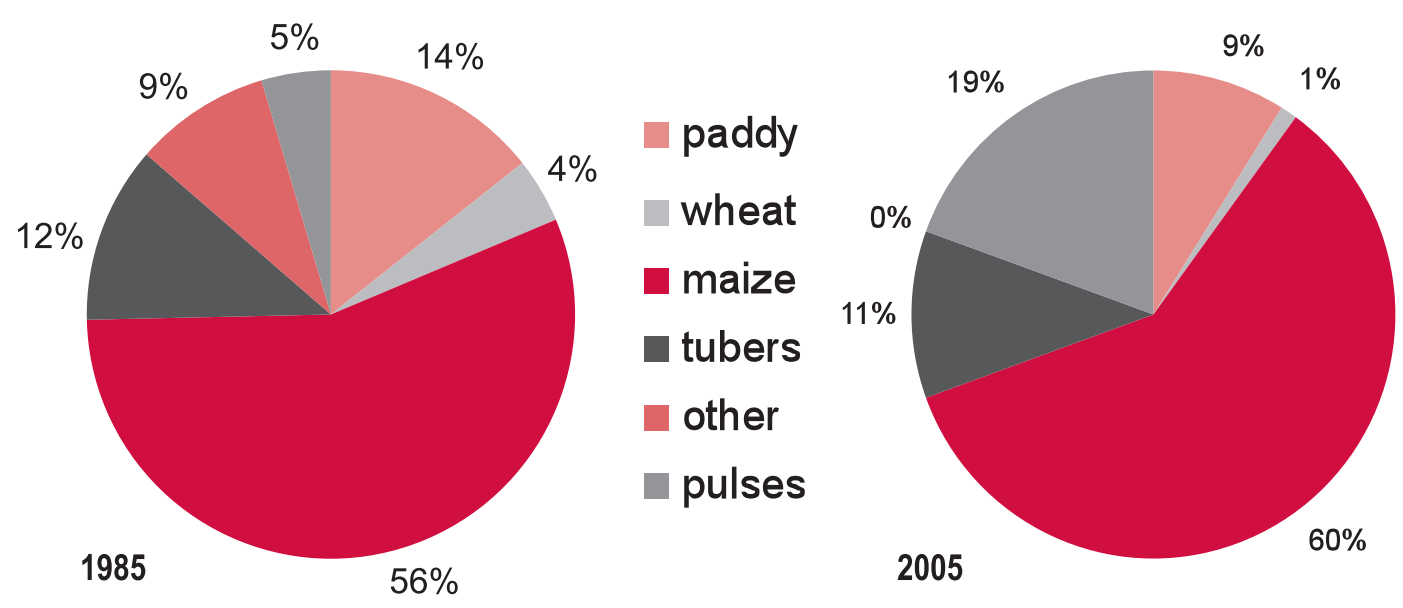

\section{Feed grain estimates}

Having made estimates for meat and other animal products, it is possible to calculate the feed grain (and fine feed) needed for each year from 1985 to 2005. We have applied grain conversion rations to the corresponding output figures of pork, eggs, poultry meat, and cow milk, based on historical data from "Agricultural Products Costs and Benefits." Calculations for the benchmark years of 1985 to 2005 are presented in Table 9, using our estimated outputs for pork, eggs, and poultry meat. For poultry meat we have deduct- ed from the total output the meat corresponding to slaughtered egg-laying hens, hens' feed being counted as feed for egg production. The outputs for cow milk use the official figures. Beef and mutton are not counted, as meat cattle and sheep are not supposed to be primarily fed with grain. Draught animals include only oxen (not water buffaloes), horses, mules, and donkeys.

Changes in animal husbandry techniques have resulted in marked changes in the grain (fine feed)/meat (or eggs or milk) conversion ratios. For pork, the fine feed figures presented in the "Cost and Benefits" surveys are relative to 
Graph 8. Grain Uses, Estimates, 1985 - 2005 (Unit: million tons)

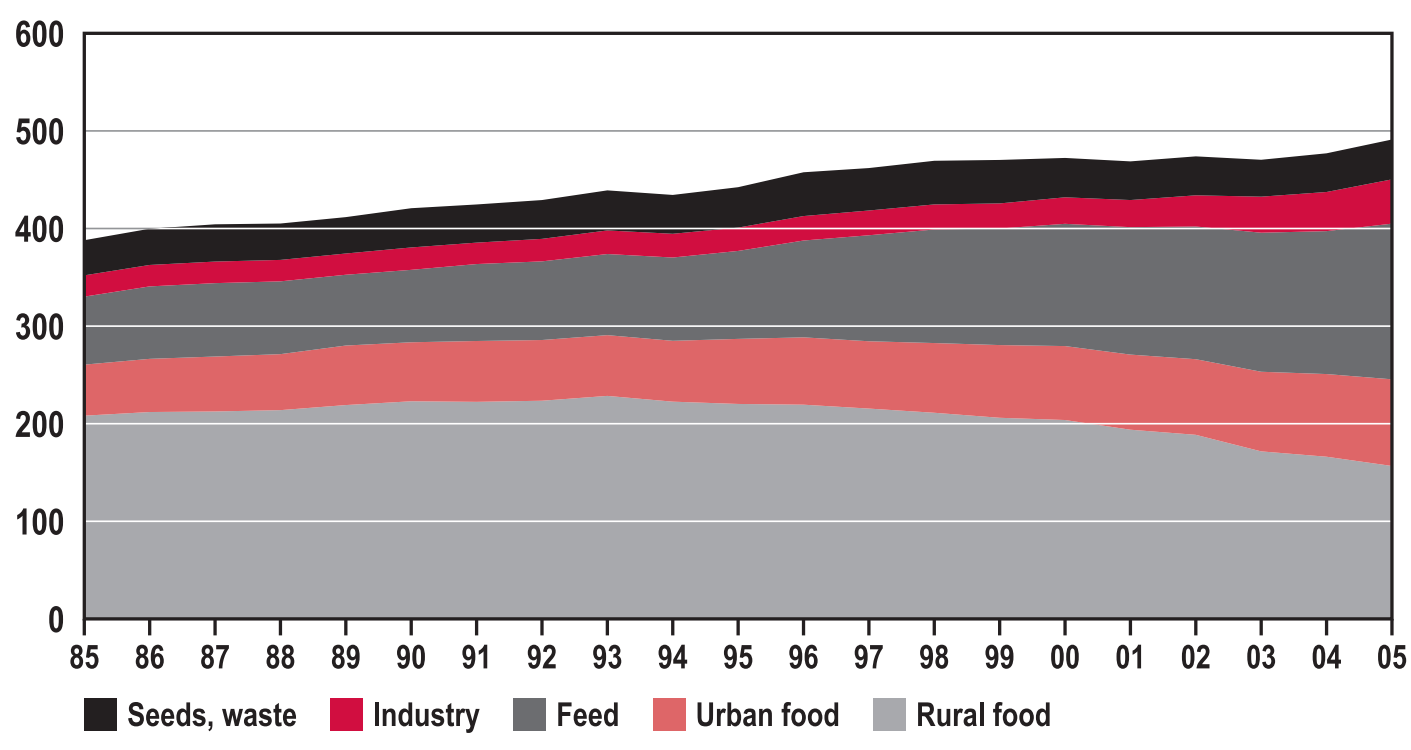

live weights, so the computed ratios are based on carcass weights estimated at 75 percent of the live weights. These ratios decreased from $4.5 \mathrm{~kg}$ of fine feed per $\mathrm{kg}$ of pork carcass in 1985 to 3.3 in 2005, reflecting the transition from traditional backyard pig raising to large-scale pig farms. The same trends are observed in the feed ratios for eggs, decreasing from 4.1 to 2.4 , and poultry meat, from 4 to 2.5. Ratios for cow milk have been assumed to remain unchanged.

From the total required fine feed we have deducted milling sub-products (as calculated from the milling of paddy and wheat used for food) to arrive at the food grain uses (including pulses in the form of soybean cakes). The resulting feed grain estimates show a doubling of the grain used for feed, from 70 million tonnes in 1985 to 160 million tonnes in 2005.

For each year, we have distributed the feed grain used among the different categories of grain (see Graph 6). Fixed quantities have been estimated for paddy and wheat, and all tubers left after food have been counted as feed. For pulses, feed corresponds with soybean cakes, other beans being counted as food (as well as soybean transformed into tofu). For secondary cereals, feed is the total left after food and industrial uses (alcohol (baijiu) from sorghum or millet). For maize, the amount used for feed is the amount left after we have deducted all other feed grain from the total feed grain needed. As this amount does not correspond exactly with the estimated amount of corn left after food and industrial uses, the differences are attributed to changes of stocks.

Given the number of assumption made, our results are open to question. In particular, the use of paddy earlier in the period could have been higher than estimated. Nevertheless, Graphs 6 and 7 give some indication of trends in feed composition over the past 20 years.

Traditional grain feeds such as corn and tubers (sweet potatoes) have maintained their importance in the total feed grain (56-60 percent for corn, 11-12 percent for tubers). Both have more than doubled in amount, from 39 million tonnes in 1985 to 95 million in 2005 for corn, which remains the main component of feed, and from 8 million tonnes to 18 for tubers. At the same time, the share of fine grains such as paddy and wheat has shrunk from 18 percent of the total to 10 percent $(16$ million tonnes altogether in 2005). Other grains have simply disappeared, having been replaced by pulses (soybean cakes), which at 31 million tonnes constituted 19 percent of the total feed in 2005 (compared with 3 million tonnes and only 5 percent in 1985). Clearly, at least in the most developed parts of the countryside (sweet potatoes are more common in poor soils or on slopes), feed composition has followed the trend of large-scale farms toward corn-soybean cakes. ${ }^{(29)}$

29. In 2004, 38 percent of the pigs slaughtered in China came from farms having more than 50 hogs' heads (deduced from the 2005 Zhongguo xumuye nianjian (Animal Husbandry Yearbook 2005), Ministry of Agriculture, Beijing, China Agriculture Press). 


\section{Special feature}

Graph 9. Grain Utilization and Output, 1985 - 2005 (Unit: million tons)

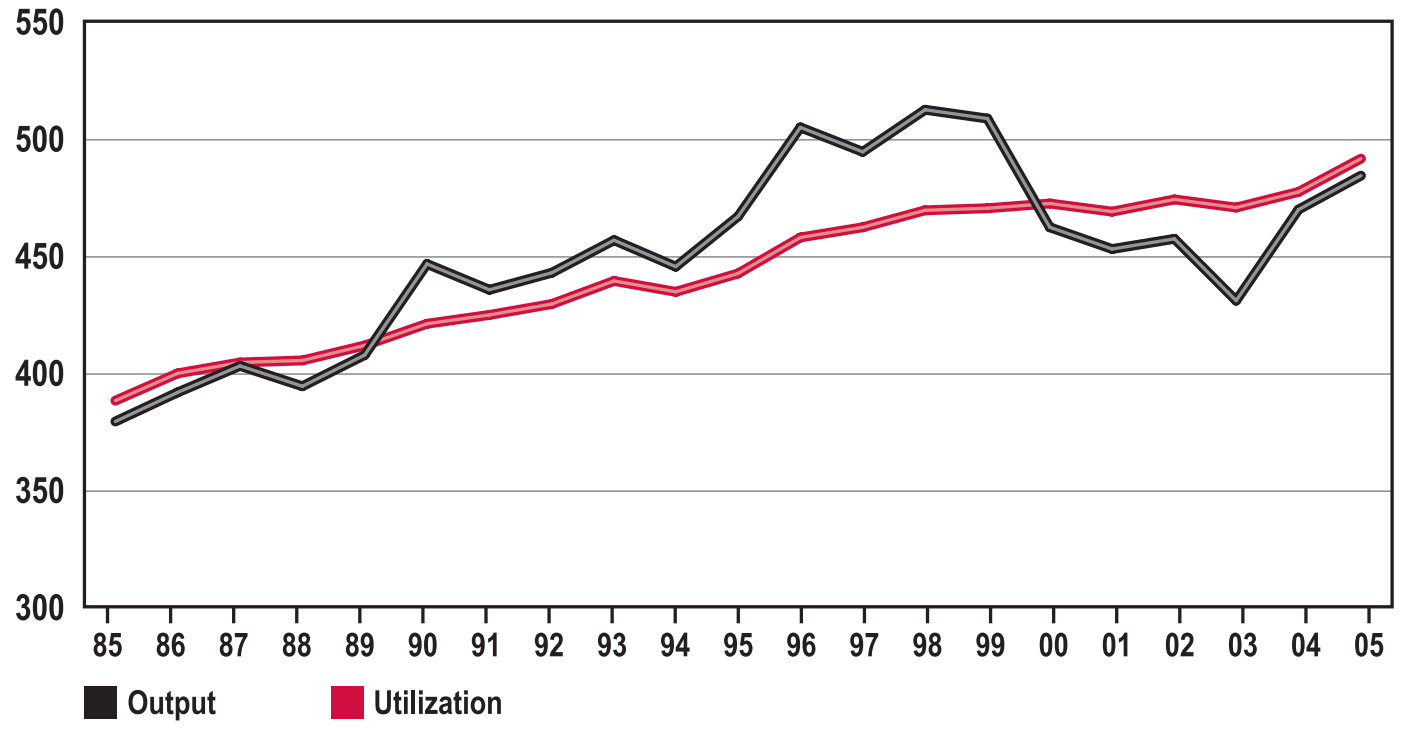

\section{Grain use and food security}

After establishing our estimates for food, feed and industry, it is now possible to see the trends in grain uses (including seeds and waste) from 1985 to 2005 (see Graph 8).

Food and feed are the two main components of grain use.
They present opposite trends, as food use has slowly but steadily decreased since the mid 1990s, while feed use has grown rapidly (see above). Any discussion of food security must therefore take account of this fundamental distinction and the different prospects for the types of grain involved. Food security can be conveniently measured by the degree

Graph 10. Grain Utilization, Output and Availability after Trade, 1985 - 2005 (Unit: million tons)

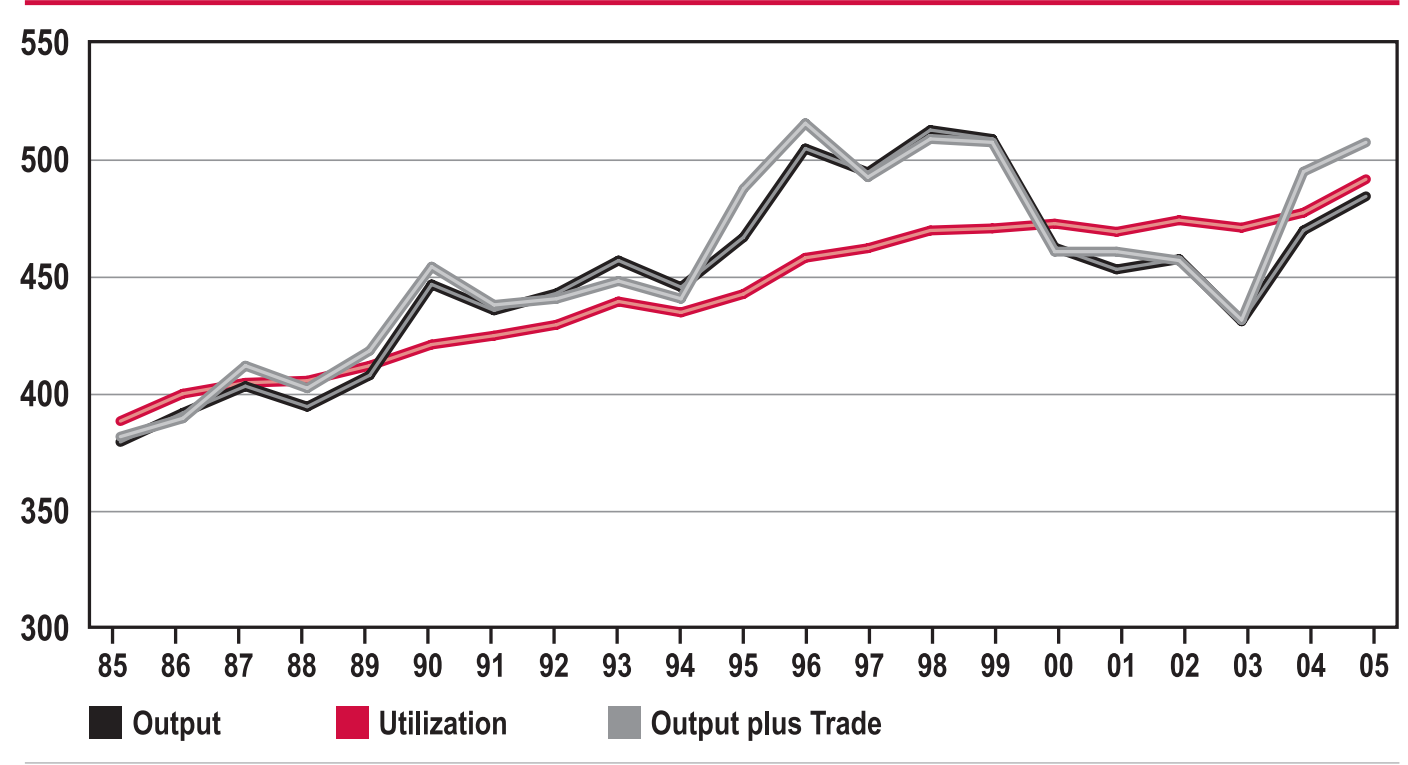


Graph 11. Wheat Prices, $1985-2005$ (Unit: current Yuan per ton)

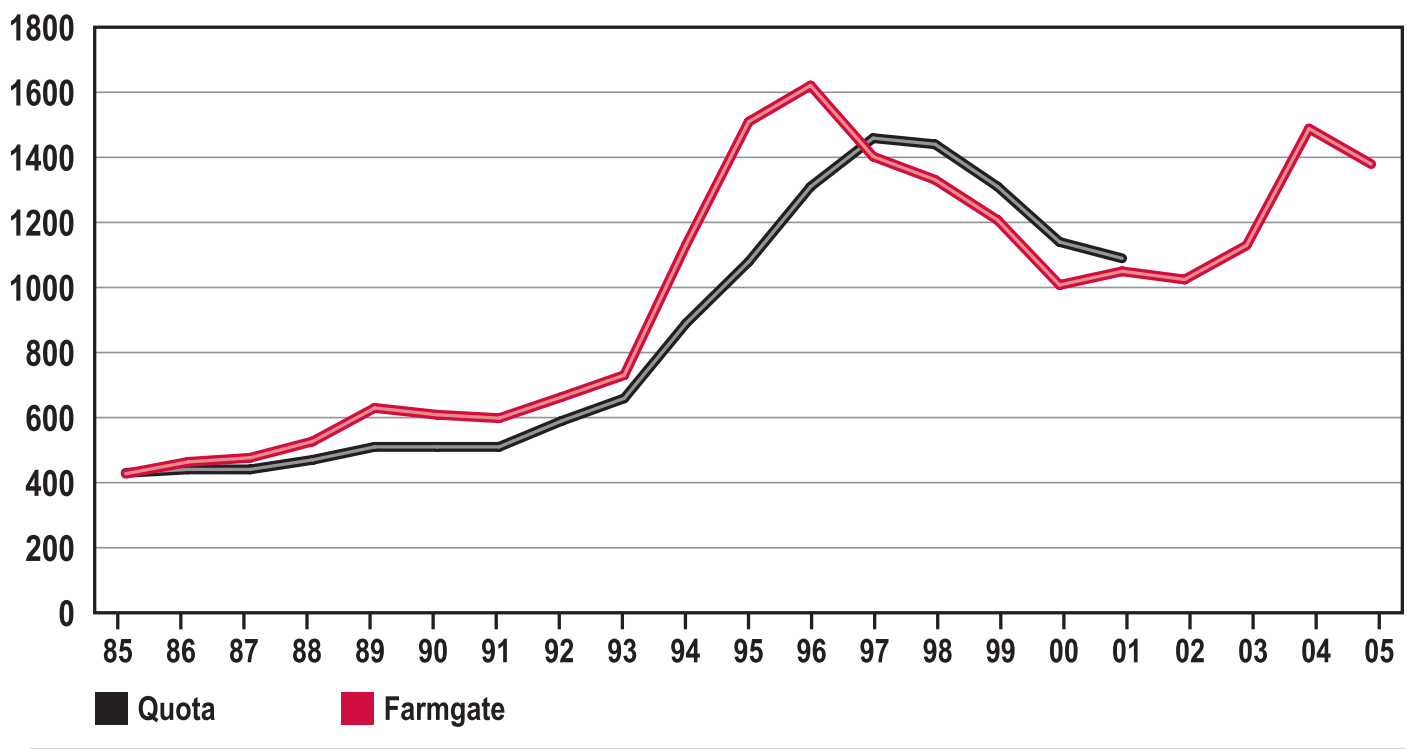

of self-sufficiency in the main grains (calculated as the ratio of output to uses, before trade). ${ }^{(30)}$ From this point of view, it would be of interest to assess the situation of the past 20 years, given that we have already estimated the total uses for this period (see Graph 9).

For the whole of the 1990s, grain output seems to be in excess, with a huge surplus beginning in 1994. This period contrasts with large deficits in the early 2000s, with balance being restored only for the last two years of 2004 and 2005. This situation is all the more astonishing in that the imbalances were not corrected by exports or imports, as shown in Graph 10, where the total availability of grain after trade is compared with the uses. It is only massive imports of soybean in the last two years that have resulted in a surplus in total availability.

The particular circumstances of these two distinct periods deserve a few words of explanation.

First, it should be noted that, with the exception of 2003, the deficit years were limited to deficits of less than 5 percent of the total utilisation. The deficit reached 8 percent in 2003 (40 million tonnes, with 430 million tonnes of output against 470 million tonnes in uses). Therefore the official goal of a self-sufficiency ratio in grain of over 95 percent was achieved in all years but 2003. However, if only cereals, and not all grains (including tubers and pulses) are counted in the calculation of the self-sufficiency ratio, the results would be somewhat different for 2003, with a deficit of 20 million tonnes, or 5 percent of uses (394 million tonnes uses against 374 million tonnes output).
Over the past 20 years, therefore, the official goal can be considered to have been basically achieved, depending on the definition of grain. ${ }^{(31)}$

30. In fact, food security was defined by the FAO in 1974 as the availability for everyone, everywhere, of enough food for sustaining a healthy life. This definition was amended in 1983 by incorporating the capacity to buy adequate food for this purpose. This concept differs from "food safety" (shipin anquan or shipin weisheng) as described by Liu Weijun et al. ("Summary research on food security understandings, problems of their origins and related policies," in Zhongguo nongcun guancha (China Rural Survey), N4, 2007, p. 67 sq.). Within the limited scope of this paper we cannot develop the problem of disparities in food grain availabilities among poor and rich areas, or among deficit and surplus regions. As concerns poverty, mainly in Western China, the official number of 23 million people living under the poverty line (683 RMB annual income per capita) is underestimated; with a poverty line fixed at 1,100 RMB, there would be 80 million poor, or over 10 percent of the rural population (Cf. Xiaolu Wang, in China Daily, 26 September 2007). According to a survey conducted in poor villages in 2005, 58 percent of the peasants could not feed themselves with their own production (Chen Qianheng and Li Junpei, "The situation of food security of farmers in impoverished regions with implications for policy," in Zhongguo nongcun jingji (Chinese Rural Economy), December 2006, pp. 20-24.). The problem is different for the grain deficit (but high income) provinces of the Eastern coast of China, which can rely on imports from the surplus areas of Central and Northern China (Cf. suggestive maps in Wei-Ming Tian et al., Chapter 9, "Zhou and Tian 2005," pp.151-152).

Another distinction has been proposed by Li Peng et al. ("China's current grain security in context of food security," in Zhongguo nongcun jingji (Chinese Rural Economy), June 2005, pp. 4-10) between the common Chinese approach of "food security" (liangsh anquan, literally "grain security") concerning only grain, and the "food guarantee" (shiwu baozhang) covering other foods as well as grain. On this basis they calculate an "ability of surplus supply." However, as grain is still the basis for a number of other foods (notably animal products), the term liangshi anquan remains significant. The authors rightly point to the decrease in direct grain consumption and the increasing feed uses (but the levels indicated in their Table 1, p. 8, are somewhat incongruous).

31. From our independent estimates incorporated into Graph 10, we can calculate that the cumulative grain balances (counted after trade) from 1985 reached 230 million tonnes at the end of the year 2005. This figure, corresponding to State and on-farm stocks, is consistent with officially published current grain inventories: "around 250 million tonnes, including the government, enterprises, and farmers" (Cf. Zeng Liying, deputy director of the State Administration of Grain, in China Daily, 5 May 2008). 
Graph 12. Wheat and Paddy Net Incomes, 1985 - 2005 (Unit: 1985 Yuan per ton)

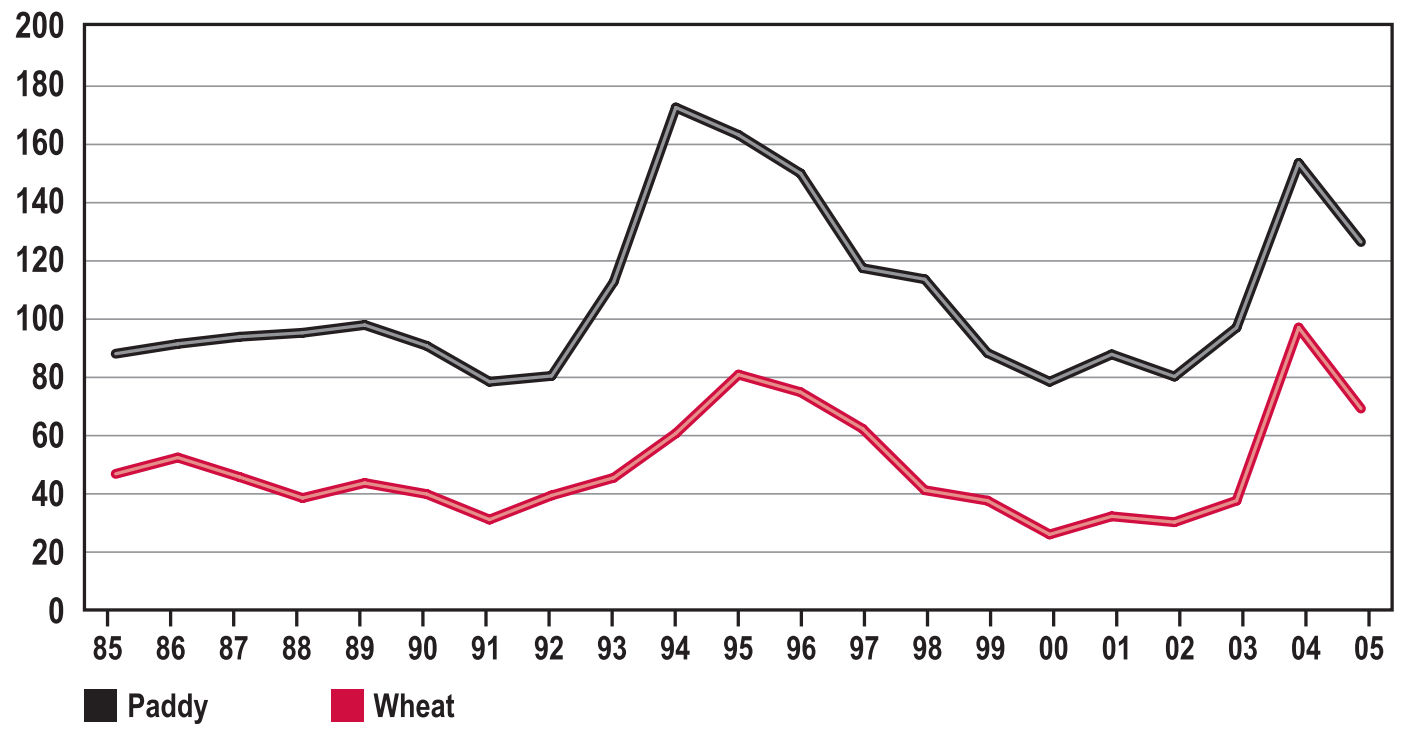

Graph 13. Wheat and Paddy Sown Surfaces, 1985 - 2005 (Unit: million hectares)

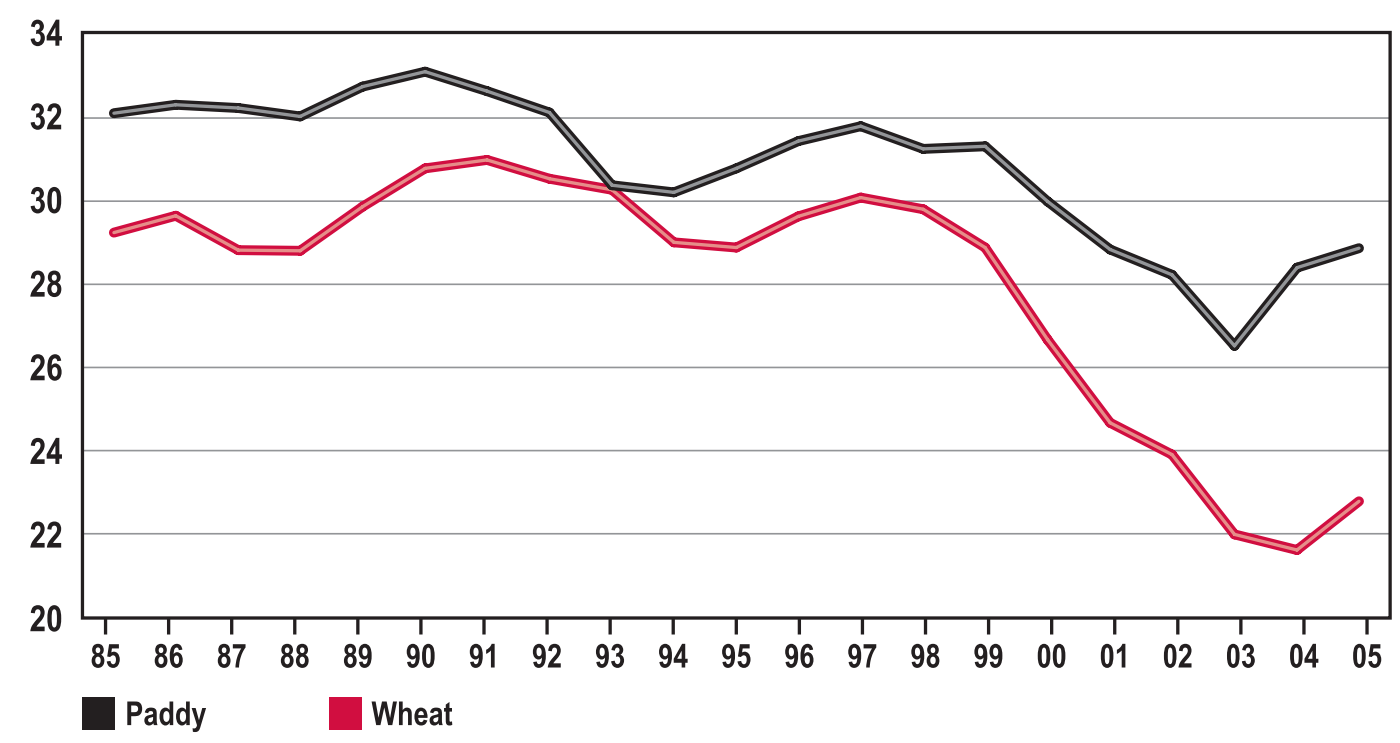

The big problem of the recent past is actually the gross imbalances that appeared in the surplus years of the 1990s contrasting with the deficit years that followed. In our opinion, these imbalances were not the result of climate or production hazards, but of the mismanagement of grain commercialisation by the state grain administration. After the failure of total liberalisation of the domestic grain trade in 1993, ${ }^{(32)}$ procurement quotas were reinstated in 1994, but at a very high level in the context of inflation at that time. Even so, the price was not high enough, as market prices were increasing even more rapidly. A kind of speculative bubble appeared in 1994-1996, with prices continuing to climb

32. We have analysed the failed reform of 1993 in a previous paper (Claude Aubert, "The grain trade reforms in China: An unfinished story of State vs. peasant interest," in China Information, vol. 12, n 3, 1998, pp. 72-86). Jiang Changyun ("A review and its inspiration from several occurrence of imbalances in grain supply and demand since the beginning of reform and opening," in Zhongguo Nongcun Guancha (China Rural Survey), N2 2006, pp. 8-15) describes this early crisis only in terms of decreased paddy output, without reference to the aborted commercialisation reform of 1993. 
Graph 14. Wheat and Paddy Outputs, $1985-2005$ (Unit: million tons)

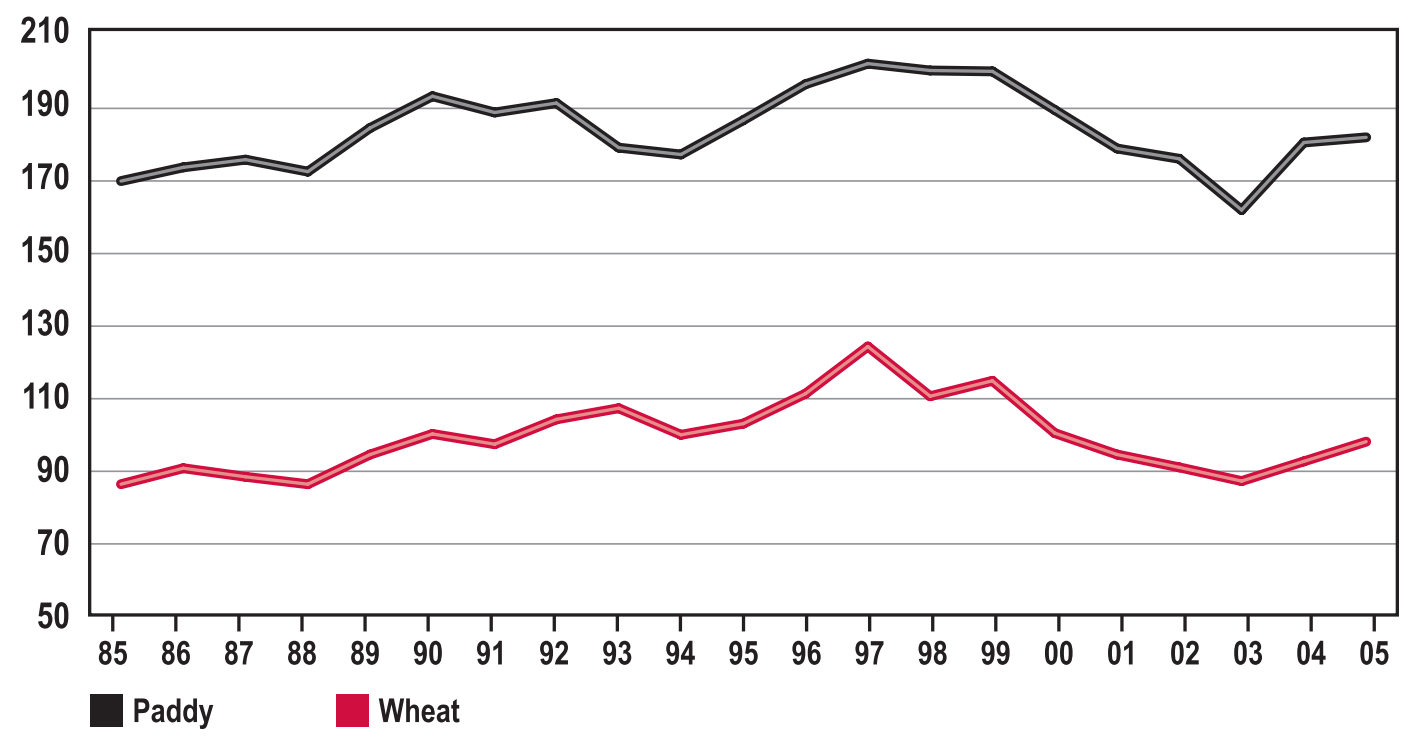

while huge surpluses were stocked by farmers or the state. ${ }^{(33)}$ The bubbled burst in 1997, with market prices dropping below procurement prices (see the example of wheat prices in Graph 11). Despite state measures to establish support prices (at an intermediary level between the high but unsustainable procurement prices and the low market prices) and forbid farmers from selling grain directly to private traders, the situation spiralled out of control. Eventually the procurement prices were progressively phased out, while market prices hit bottom in 2000-2002. The whole procurement system was finally abolished in 2004. In 2003, the selling of stock pushed prices to their lowest level, and output was down by a big margin. The following year, market forces finally pushed up the prices, and the crisis was soon over.

The result of the price drop was diminishing profits from the main grain cultivation (see the examples of net incomes from wheat and paddy in Graph 12). The peasants reacted to this situation, first by selling their stocks, then by decreasing their sown surfaces (see example of wheat and paddy, Graph 13). The result, with unchanged yields, was a drop in output (Graph 14). Wheat dropped from 123 million tonnes to 86 million, and paddy from 201 to 161 . The total grain harvest then fell from 512 million tonnes in 1998 to 431 million tonnes in 2003. With the rebound in prices and benefits in 2004, grain output recovered to 484 million tonnes in 2005 (and 497 million tonnes in 2006).

Throughout the crisis, grain deficits were offset by putting huge farm and state stocks on the market so that no imports were needed (see cereal net trade, Graph 15). Corn even achieved net exports of 16 million tonnes by 2003. Wheat imports remained negligible until 2003 (followed by 5 million tonnes imported in 2004, for tackling the previous year's wheat deficit and depleted stocks), and rice exports remained stable.

What could have been a serious grain security crisis was only a rectification of the grain market after the bubble of the mid-90s. This applies, however, only to cereals, as soybean imports have exploded in recent years (up to 28 million tonnes in 2006, see Graph 16). This should remind us that at present and for the foreseeable future, prices are likely to remain the main determinant for output levels and therefore for grain security among the main food cereals.

33. The problem of stocks was first analysed by Frederick Crook (Frederick W Crook, "China's Grain Stocks: Background and Analytical Issue," in International Agriculture and Trade Report: China, U.S. Department of Agriculture, Economic Research Service, WRS96-2, June 1996, pp. 35-39). In our previous paper in Déméter 2005, we made estimates of on-farm carry-over stocks based on the year-end stocks reported in the NCBS rural surveys, and deducting the provisions for food, feed, and seeds of the following year. Ke Binsheng (in Chapter 8 of Yongzheng Yang and Weiming Tian, (ed.), China's Agriculture at the Crossroads, London, MacMillan, 2000, pp. 118-128) made the same calculations, but applied a uniform rate of 25 percent of year-end stocks to estimate carry-over stocks, whatever the level of stocks each year. According to our estimates, these stocks increased from about 110 million tonnes in 1991 to 285 million in 1998. At that time, the state stocks were estimated at 235 million tonnes, which combined with on-farm stocks totalling an astonishing 520 million tonnes, equivalent to one year's output. Wan Guanghua and Zhang Ouxiang have made an interesting analysis of how peasant behaviour affected the stocks, concluding that the effect of prices was exacerbated by irrational assessments of the situation ("Determinants for farmers' households grain storage in China: Does price matter?" in Zhongguo nongcun jingji (Chinese Rural Economy), May 2007, pp. 13-23). 
Graph 15. Cereal Net Trade, 1987 - 2006 (Unit: million tons)

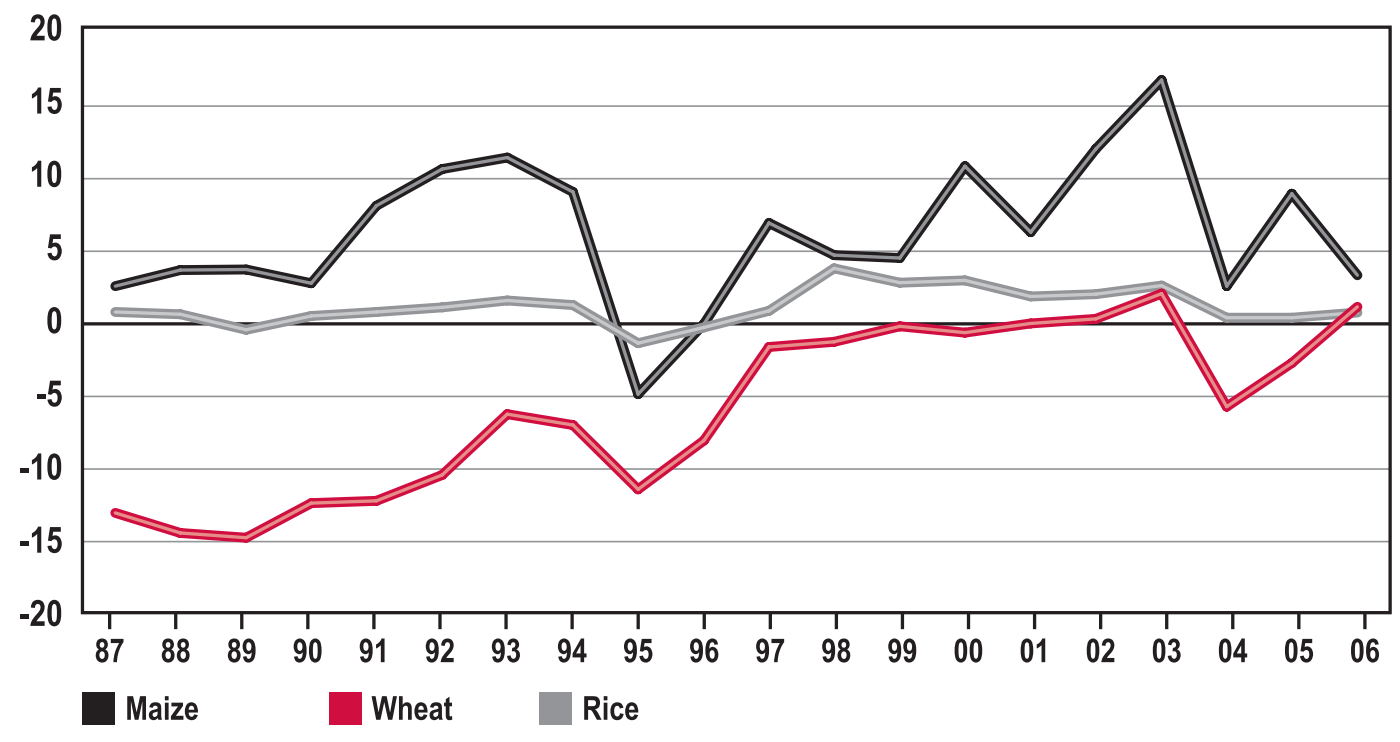

\section{Conclusion}

In short, our analysis of consumption patterns during the last 20 years in China concludes that the so-called "grain problem" is a purely statistical artefact. While it is true that Chinese data are misleading and official figures for meat output are greatly over-estimated, ${ }^{(34)}$ once the necessary corrections are made, the resulting estimates indicate that food security was achieved despite an unprecedented change in consumption patterns with the transition from grain to meat.

According to our very conservative estimates, meat output would have grown from 20 million tonnes in 1985 to 57 million in 2005, with gross availability per capita more than doubling from $18 \mathrm{~kg}$ to $43 \mathrm{~kg}$. This is indeed a great achievement, considering that it was reached while securing a grain self-sufficiency ratio (as defined by the ratio of domestic output to all uses before trade) of 95 percent or greater, the only exception being the year 2003, when this ratio dropped to 92 percent. The big challenge for Chinese agriculture in the past two decades was not only to provide enough food for a growing population, but also to allow transition to a meat-oriented diet. This challenge has been met with success while food security was preserved.

This rosy conclusion might appear at odds with the present situation of worldwide food price inflation. Some media even put blame on China, alleging that increased meat consumption there is behind the rising price of foodstuffs, particularly cereals, worldwide. This could not be more wrong. While
China is a major importer of soybean (counted as "grain") at 30 million tonnes in 2007, this situation is not new, and the very high import levels in previous years (28 million tonnes in 2006, 26 million in 2005) did not result in a worldwide inflation of cereal prices such as that observed since 2007. On the contrary, China was a net exporter of cereals in 2007: five million tonnes of corn, three million tonnes of wheat, and one million tonnes of rice. ${ }^{(35)}$ Indeed, the increase in rice and wheat retail prices in China in 2007 actually resulted from inflation in these prices in the world market. ${ }^{(36)}$

Having said that, the present situation may not last forever, and the "grain problem" could actually arise in the near future. In this regard, we recommend considering two main aspects: first, short-term (the next few years) versus longerterm prospects; and secondly, prospects for food grain (main-

34. The NBSC official "Statistical Communique of the People's Republic of China on the 2007," 28 February 2008 (Cf. http://www.stats.gov.cn/), indicates that the total output of meat for 2007 was 68 million tonnes, 3.5 percent lower than the previous year. If this figure is confirmed by later publications, it would mean that the meat output for 1996 was 70.4 million tonnes, compared with the 80.5 million tonnes quoted for that year in the Statistical Yearbook 2007 (p. 485). In other words, following the Agricultural Census of 2007 (figures for the end of 2006), the meat output would have been revised downward by 12.5 percent.

35. Chinese Ministry of Agriculture, 4 February 2008. These exports are in line with the high level of state stocks, which the USDA estimated at 115 million tonnes for the end of the agricultural year 2007-2008 (Cf. USDA, Foreign Agricultural Service, People's Republic of China, Grain and Feed, Annual 2008, 1 March 2008).

36. Cf. Jikun Huang in People's Daily, 24 March 2008. In order to limit food prices inflation, China has tried to stop exports of cereals for the year 2008 by scraping former export VAT rebates and installing instead export tariffs (Cf. China Daily, 30 December 2007). The result has been a slowing of the cereals domestic prices' growth, contrasting with the surge of world market prices (Cf. Jikun Huang, Scott Rozelle and Hanguang Qiu, "Food prices and inflation in China", in CLSA U, May 2008). 
Graph 16. Soybean Net Trade, 1987 - 2006 (Unit: million tons)

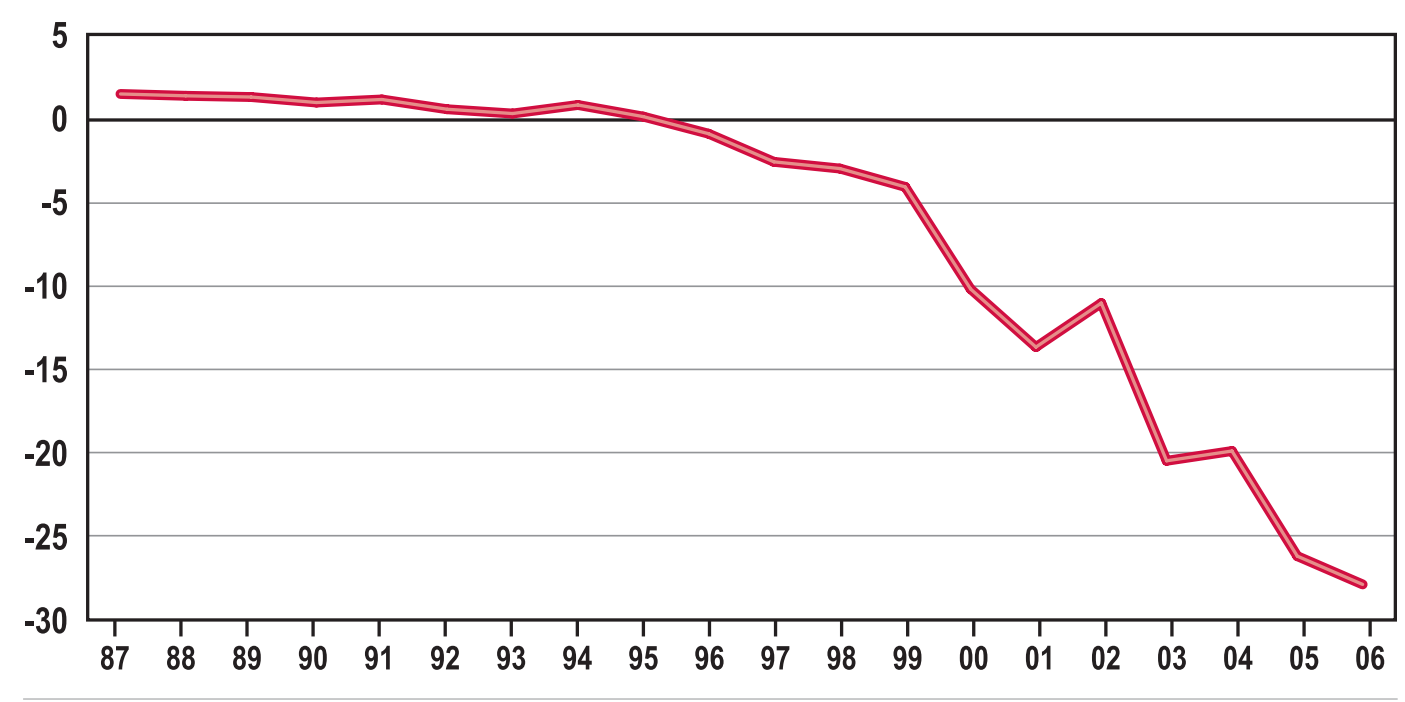

ly paddy and wheat) versus feed grain (corn and soybean). For the short term, prices of wheat and paddy will remain the main factors in output levels and therefore in the degree of self-sufficiency for China. The declining trend in total rice and wheat food consumption should facilitate this objective of self-sufficiency, and the current high prices should provide Chinese farmers with incentive to produce and sell enough staple food grains. However, rising material costs (fuel oil, seeds, and fertilizers) may offset the benefits of higher producer prices. In order to tackle this problem, the Chinese government has already raised the minimum purchase prices for rice and wheat while substantially increasing direct subsidies to farmers. ${ }^{(37)}$ More generally, the present context of volatile international prices may put into question the very concept of food grain security. ${ }^{(38)}$

The situation differs for feed grain. China is already short on corn (the present exports, 5 million tonnes for 2007, are probably speculative sales of stock due to the high world trade market prices), and presents a high deficit for soybean. Larger imports of soybeans, and imports of corn at some point, can therefore be expected. The very high price of feed is already affecting pig farms (still recovering from the "blue ear" epidemic) as well as the dairy industry, translating into high prices for meat. The resulting inflation penalises low-income urban dwellers, but does not imperil global food security based on staple food grain.

For the middle and long term, prospects are much more difficult to assess, with uncertainties quite high for future harvests. The lack of water resources in northern China will be exacerbated by pollution and competition from urban and industrial uses. Climate vagaries have already appeared, with unusual droughts in southwest China, and cold winter and snow in south and central China. In the long term, climate change will affect the whole cropping system of China, rending projections inoperable. ${ }^{(39)}$ If the "grain problem" is purely statistical at present, there is a real danger that it will someday become an intractable and frightening reality in China, as well as in the rest of the world. •

\section{People's Daily, 28 March 2008.}

38. Wang Yapeng ("Reflections on optional paths for China's food security," in Zhongguo nongcun jingii (Chinese Rural Economy), March 2005, pp. 4-11), with reference to the 2001-2003 grain crisis, reminds us of the strategic character of food grain, and underlines the necessity of a minimum self-sufficiency that takes account of the uncertainties of the WTO and the difficulty of replacing grain farming with high-value agricultural products that face quality and standardisation obstacles as exports.

On the other hand, Jiang Changyun ("To coordinate the relations between food security and income growth of the farmers," in Nongye jingji wenti (Issues in Agricultural Economy), February 2005, pp. 44-48) argues that a 10 percent deficit in grain (on the basis of 490 million tonnes of consumption and 20 million tonnes of imports for soybean) would result in only 29 million tonnes of cereal deficit, comparable to the imports of Japan, and would be unable to trigger a significant rise in worldwide prices as long as the progression of imports is smooth and spread over a number of years.

39. Chen Yongfu ("Supply and demand of grain in China: A projection," in Nongye jingji wenti (Issues in Agricultural Economy), April 2005, pp. 8-13) nonetheless uses his own model to make projections for the year 2020: 3.3 million tonnes net exports for paddy, 8.3 million tonnes net imports for wheat, 24.7 million tonnes net imports for corn, and 36.3 million tonnes net imports for soybean.

Wen James Guanzhong (Chapter 12, in Xiaoyuan Dong, Shunfeng Song, and Xiaobo Zhang (ed.), China's Agricultural Development, challenges and prospects, Aldershot, Ashgate, 2006, pp. 207-239), presents different scenarios, depending on population growth, grain/meat (and other animal products) ratios, and production growth, which result in divergent figures according to the specified scenarios: from 90 million tonnes deficit for the year 2020, in the case of high population, and low supply (Cf. Ibid. p. 232). 